\title{
Review on Occupational Personal Solar UV Exposure Measurements
}

\author{
Alois W. Schmalwieser $1, * \mathbb{C}$, Giuseppe R. Casale ${ }^{2}$, Alfredo Colosimo ${ }^{3}{ }^{\circledR}$, Susanne S. Schmalwieser ${ }^{4}$ \\ and Anna Maria Siani ${ }^{5}$ (D) \\ 1 Unit of Biophysics and Physiology, University of Veterinary Medicine, A-1210 Vienna, Austria \\ Independent Researcher, I-04020 Monte San Biagio (LT), Italy; giuseppe.casale@uniroma1.it \\ Independent Researcher, I-00152 Rome, Italy; alfredo.colosimo@uniroma1.it \\ 4 Karl Landsteiner Privatuniversität für Gesundheitswissenschaften, A-3500 Krems, Austria; \\ susanne.schmalwieser@kl.ac.at \\ 5 Department of Physics, Sapienza Università di Roma, I-00185 Rome, Italy; annamaria.siani@uniroma1.it \\ * Correspondence: alois.schmalwieser@vetmeduni.ac.at
}

check for

updates

Citation: Schmalwieser, A.W. Casale, G.R.; Colosimo, A.;

Schmalwieser, S.S.; Siani, A.M.

Review on Occupational Personal

Solar UV Exposure Measurements.

Atmosphere 2021, 12, 142. https://

doi.org/10.3390/atmos12020142

Received: 7 November 2020

Accepted: 13 January 2021

Published: 23 January 2021

Publisher's Note: MDPI stays neutral with regard to jurisdictional claims in published maps and institutional affiliations.

Copyright: (c) 2021 by the authors. Licensee MDPI, Basel, Switzerland. This article is an open access article distributed under the terms and conditions of the Creative Commons Attribution (CC BY) license (https:// creativecommons.org/licenses/by/ $4.0 /)$.
Abstract: During leisure time, people can decide if they want to expose themselves to solar ultraviolet (UV) radiation and to what extent. While working, people do not have this choice. Outdoor workers are exposed to solar UV radiation (UVR) on a daily basis. This may pose a certain health risk, which can be estimated when the personal solar UVR exposure (PE) is known. During past decades, a variety of studies were conducted to measure PE of outdoor workers and our knowledge of the PE of outdoor workers has increased remarkably. As shown by this review, studies clearly indicate that $\mathrm{PE}$ of most outdoor workers exceeds the internationally proposed threshold limit value, which is comparable to 1.0 to 1.3 standard erythema dose (SED), respectively, to 1.1 to $1.5 \mathrm{UV}$ Index received over one hour. Besides working in a high UVR environ, monotonic workflow (limited movement, nearly static posture) is a risk factor. In such cases, PE can be higher than ambient UVR. In this review, we provide also a list of milestones, depicting the progress and the most important findings in this field during the past 45 years. However, in many respects our knowledge is still rudimentary, for several reasons. Different measuring positions have been used so that measured PE is not comparable. Few studies were designed to enable the extension of measured PE to other locations or dates. Although the importance of a proper calibration of the measuring devices in respect to the changing solar spectrum was pointed out from the beginning, this is often not performed, which leads to high uncertainties in the presented PE levels. At the end of our review, we provide some key points, which can be used to evaluate the quality of a study respectively to support the design of future studies.

Keywords: solar UV radiation; UV exposure; occupational UV exposure; personal UV exposure; exposure ratio to ambient UV; UV exposure measurements

\section{Introduction}

Ambient ultraviolet (UV) radiation (280-400 nm) comprises about 5\% of the total solar radiation reaching the Earth's surface. It is usually divided into UV-A (315-400 nm), UV-B (280-315 nm), and UV-C (100-280 nm); the latter is completely absorbed in the upper atmosphere by ozone and oxygen. There is a variety of environmental parameters with large natural variability, which affect the variability of terrestrial UV-A and UV-B levels (e.g., [1]).

Human exposure to solar UV radiation (UVR) also depends on a variety of factors, including human behavior, the amount of time spent under the sun, the activity (work or leisure), and the location (urban areas, mountains, beaches).

There is a general consensus that exposure to solar UVR (further called as UV exposure) can have a detrimental (acute and/or chronic) effects on unprotected skin and/or eyes with deterministic (e.g., erythema, conjunctivitis, etc.) or stochastic characteristics (e.g., 
skin cancer, cataract, etc.). On the other hand, a small amount of UV-B exposure is needed to activate vitamin D production (e.g., [2]). This bi-faceted biological role of UVR has attracted commensurable interest in the recent years. However, the balance between risks and benefits of solar UVR under different exposure conditions is not yet fully understood.

In any case, continuous long-term exposure to solar UVR leads to visible changes in fair skin. These were recognized early in outdoor workers and named "farmer's or seafarer's skin" [3]. Measureable changes already result from sub-erythemal exposure [4,5]. The underlying mechanisms are a thickening of the outermost layers of the skin and increased pigmentation (tanning). Continuous UV exposure leads to a 3- to 5-fold thickening of the stratum cornea, which develops after several weeks. Normally, this effect vanishes within 4 to 8 weeks after UV exposure has stopped. However, in outdoor workers, the continuous UV exposure inhibits the return to pre-exposure conditions. Thickening of the skin is an effective protection in all photo skin types and may lead to a UV protection factor of 4 to 5 [6], whereas the absorption coefficient increases most strongly in UV-B [7]. From that, a noticeable protection against those wavelengths, which are very effective in causing damage (e.g., erythema), is delivered. In lightly pigmented individuals, thickening of the skin is much more effective than pigmentation. In those who have the ability to tan, pigmentation starts to increase one or two days after solar UV exposure and persists over weeks. Pigmentation (in the absence of skin thickening) may result in a UV protection factor of 2 to 4 [8].

Prior to 1970, skin cancer was typically a disease of outdoor workers such as farmers and seamen [9]. However, due to changes in social activity, it has become a disease of the general public. People's intermittent exposure from recreational activities [10] contributes considerably to total exposure to solar UV radiation. According to the WHO (World Health Organization), skin cancer represents one of the most common cancers in fair-skinned populations. The incidence rate of both melanoma and non-melanoma skin cancer has increased worldwide in the last decades [11,12]. Based on this evidence, the International Agency for Research on Cancer (IARC) classified solar radiation, the main source of human exposure to UVR, as "carcinogenic to humans" [13].

The probability of developing non-melanoma skin cancer (i.e., the incidence rate) primarily depends on the personal genotype (sensitivity, self-repair ability, etc.), the cumulative UV exposure, which is influenced by the self-protection ability of the skin and external sun protection measures, and age. These factors are independent of each other. Cumulative UV exposure and age contribute exponentially [14]. In detail, the relationship between UV radiation and the various skin tumors is different. Even with the non-melanoma skin cancer, a distinction must be made in this respect between squamous cell carcinomas and basal cell carcinomas. It is likely that the relation is similar for other accumulating effects. From this exponential contribution, it becomes clear that occupational UV exposure raises the potential health risk remarkably and field campaigns on occupational solar UV exposure can provide objective measures of personal UV exposure and related risk.

In many countries, there is still no legislation or government program regarding measures to protect outdoor workers from UVR exposure. A notable exception from this is Australia, where significant concern about UVR-induced diseases has been expressed for almost 30 years [15]. In the European Union, the by-law EG 2016/425 came into force in 2018 and directs UV protective clothes (for outdoor workers) as part of the personal protective equipment that has to fulfill certain requirements. In respect to health care and social insurance, non-melanoma skin cancer (e.g., squamous cell carcinoma) and actinic keratosis is approved as work-related disease in just a few countries.

Quantification of human UV exposure is a complex issue, because the differently oriented body parts receive changing levels of solar UVR which itself changes continuously (intensity and direction). For this reason, UV exposure is directly related to ambient UVR (incoming UV irradiance on a flat horizontal surface) as well as to a variety of factors such as the orientation of the exposed anatomical site during outdoor activities, the duration of 
exposure in shady places or under clear/cloudy sky conditions. Quantification is carried out by attaching volunteers with small sensors, which are sensitive to UVR only.

This paper aims at providing an overview of studies on the quantification of occupational exposures to solar UVR from the beginning in the early 1970s until now, as well as a summary of the milestones over the period under study.

\section{Literature Search}

Studies on occupational exposure published in the literature were identified via the search engines "Scopus" (Elsevier, The Netherlands) and "PubMed" (U.S. National Library of Medicine National Institutes of Health). The query search strategies involved the terms "ultraviolet personal exposure" in titles, abstracts and keywords. More than 800 articles matched these parameters. An accurate refinement analysis of these articles and crossreferences led finally to the selection of 60 studies.

\section{Results}

In this section, we provide a chronological overview on studies conducted on personal UVR exposure (PE) of outdoor workers. Milestones, which have significantly contributed to the understanding of PE, are also included. Especially for the early days of PE measurements, we would like to refer to the most recent paper of Brian L. Diffey [16], who pioneered and provided key contributions to this scientific field from the beginning.

\subsection{The 1970s and 1980s}

The first attempt to estimate PE qualitatively was undertaken by Frank Urbach [17], who attached badges from a chemical material on a manikin, mainly on different sites of the head. This chemical material changed color in relation to UV exposure. He showed that the most exposed locations of the head were those where squamous-cell carcinomas predominantly occur.

Shortly after, Davis, Deane and Diffey [18] demonstrated that polysulphone film (PSF) can be used for quantitative measurements of PE in respect to the erythema response. They conducted a first field study [19] involving laboratory workers, gardeners and hospital patients. The volunteers wore the PSF on the lapel site for over two weeks around the summer solstice in England, when the weather was particularly sunny. Beside overexposure of these targeted populations, the study took chronic underexposure into account, which was identified by low levels of vitamin D at that time in England-for example in the elderly, in submariners and in Asiatic immigrants. The difference between the action spectrum (i.e., the effectiveness of UVR to produce a biological response in dependence of wavelength) of erythema [20] and the spectral response of PSF was corrected by a daily comparison of a PSF badge to an electronic radiometer (called a Roberston-(Berger) Meter or sunburn meter [21,22], that measures the erythemally effective UVR. The exposure ratio to ambient UV radiation (ERTA), defined as the percentage of the personal UVR exposure at a given anatomical site compared with that of the ambient UVR (i.e., incoming UVR on a flat horizontal surface), was estimated separately for the working week and the weekend. Two gardeners received around 10\% of ambient UVR during working activities. The nine laboratory workers received $2 \%$ during working days, but around $5 \%$ on days off and, therefore, an essential contribution to their cumulative PE. The authors mentioned a broad variation in daily PE resulting from weather, time of the day when outside, and from personal habits.

As PE was measured at the lapel site, Diffey et al. [23] investigated the anatomical distribution of PE and the possible influence of cloudiness. For this, 10 PSF badges were mounted all over a rotating manikin for three weeks. Beside the body distribution, it was found that cloudiness has a minor influence on the relative PE distribution during continuous (random) movement, like that of working people.

In a next step, the seasonal variations in PE of office workers were investigated [24] by equipping 50 of them and a housewife with PSF badges on the lapel site. Measurements 
of PE and ambient UVR were carried out around the equinoxes and solstices for around 2 weeks each. From these, the annual pattern of PE was estimated. It became evident that not only did the PE vary within the year, but the same occurred also for the ERTA, which varied from around $5 \%$ in summer to $2 \%$ in February (holidays not included). The ERTA for the housewife was up to $15 \%$ in summer and $5 \%$ in winter. Again, a broad distribution of PE in indoor workers was found.

Due to the good performance of PSF, Diffey et al. [25] decided to repeat the experiment of Frank Urbach with quantitative measurements. Using dozens of PSF badges on a giant human head model, they compared the UV exposure to the observed tumor distribution. A high correlation was found; however, a certain influence of unknown origin on nonmelanoma skin cancer was suggested.

It was pointed out early that time and duration play an important role for PE. Hence, in 1978, Corbett et al. [26] introduced the use of a diary for hourly entries into a nonoccupational UV exposure study to estimate the time when people stayed outdoors in the sun and the duration of exposure. Since then, diaries have been further refined and adapted. Figure 1 visualizes an example for a diary on an hourly basis. Participants record weather, main posture, shadowing, clothing, altitude and activity.

\begin{tabular}{|c|c|c|c|c|c|c|c|c|}
\hline $\begin{array}{c}\text { Datum: } \\
13.09 .2005\end{array}$ & 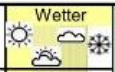 & | & $\varnothing_{+}^{\text {Beschattung }}$ & $g^{80} a$ & Bekleidung & \begin{tabular}{||c|}
$\begin{array}{c}\text { See- } \\
\text { Höhe } \\
\text { in m }\end{array}$ \\
\end{tabular} & \begin{tabular}{|c|} 
Tätigkeit \\
$1-14$ \\
\end{tabular} & $\begin{array}{l}\text { Name: } \\
\text { Max Mustermann } \\
\text { Außentätiqkeit: }\end{array}$ \\
\hline $06: 00$ & & & & & & & & WEINBAU / OBSTBAU: \\
\hline 07:00 & & & & & & & & \begin{tabular}{|l|l|}
1 & Anlagenbereitung /-pflege \\
\end{tabular} \\
\hline 08:00 & & & & & & & & \begin{tabular}{|l|l|}
2 & Bodenbearbeitung \\
\end{tabular} \\
\hline 09:00 & & & & & & & & \begin{tabular}{|l|l|}
3 & Rebschnitt/ Baumschnitt \\
\end{tabular} \\
\hline 10:00 & & & & & & & & \begin{tabular}{|l|l|}
4 & Pflanzenschutz / Düngung \\
\end{tabular} \\
\hline 11:00 & & & & & & & & \begin{tabular}{|l|l|}
5 & Weinlese / Obsternte \\
\end{tabular} \\
\hline $12: 00$ & & & & & & & & ACKERBAU / GRÜNLAND: \\
\hline 13:00 & & & & & & & & \begin{tabular}{|l|l|}
6 & Bodenbearbeitung (Feld, Wiese) \\
\end{tabular} \\
\hline 14:00 & & & & & & & & \begin{tabular}{|l|l|}
7 & Anbau \\
\end{tabular} \\
\hline 15:00 & & & & & & & & \begin{tabular}{|l|l|}
8 & Pflanzenschutz/ Düngung \\
\end{tabular} \\
\hline 16:00 & & & & & & & & \begin{tabular}{|l|l|}
9 & Ernte / Transport \\
\end{tabular} \\
\hline 17:00 & & & & & & & & \begin{tabular}{|l|l|}
10 & Lagerungsarbeit (aussen) \\
\end{tabular} \\
\hline 18:00 & & & & & & & & MISCHBETRIEBE inkI. Berglandwirtsch. \\
\hline 19:00 & & & & & & & & \begin{tabular}{|l|l|} 
Weinbau / Obstbau (1-5) \\
\end{tabular} \\
\hline $20: 00$ & & & & & & & & Ackerbau/Grünland (6-10) \\
\hline \multirow{4}{*}{\multicolumn{8}{|c|}{ Bemerkungen: }} & \begin{tabular}{|l|l|}
11 & Waldbau, Forstarbeit \\
12 & Viehtrieb bei Nutztierhaltung \\
\end{tabular} \\
\hline & & & & & & & & \begin{tabular}{|l|l|}
13 & sonstige Außentätigkeit \\
\end{tabular} \\
\hline & & & & & & & & Innentätigkeit: \\
\hline & & & & & & & & \begin{tabular}{|l|l|}
14 & Innentätigkeit \\
\end{tabular} \\
\hline
\end{tabular}

Figure 1. Example of an (electronic) diary based on the idea of Corbett et al. [26] designed for a farmer Study [27]. Recorded are weather, posture, shadow, clothing, altitude and activity.

In the 1980s, the phototherapy of psoriasis patients with UV-B radiation was well established. Diffey et al. [28] cared for the exposure received by these patients and compared therapeutic UVR exposure to that from natural sun when engaging in different leisure activities. In a following study [29], exposure from therapy was compared with that received (lapel site) by outdoor (military, fishermen, farmers), mixed-indoor-outdoor and indoor occupation in Sweden in June and August. Therapy was found to contribute by 30\% to the PE of outdoor workers but $50 \%$ to $100 \%$ to that of indoor workers. By comparison with the results presented in 1982 [28], it became evident that 3 weeks of sunbathing in the Mediterranean area is 1.5 times the annual exposure of Swedish indoor workers and a quarter of that of outdoor workers; 3 weeks of sightseeing in Central Europe adds $40 \%$ to annual PE of indoor workers; 3 weeks of sailing in Sweden adds 20\%. Looking at the broad distribution of participants' PE, they found that the PE distribution in each group has a positive skewness. Such a distribution needs appropriate statistical parameters for description (median, skewness, percentiles) (see Figure 2). 


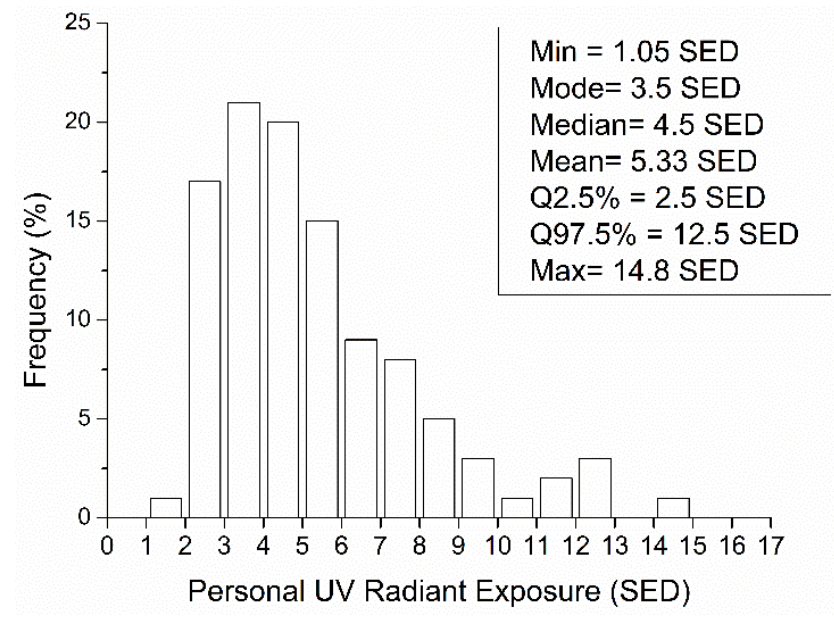

Figure 2. Example of the typical frequency distribution of PE like that found by Larkö and Diffey [29] and others. Indicated are the appropriate statistical descriptors: minimum (Min), 2.5\%-percentile (Q2.5\%), mode, median, mean, 97.5\%-percentile (Q97.5\%) and maximum (Max). The percentiles indicate the $95 \%$ confidence interval. The distribution has right skewness as mode, median and mean differ as well as the distances between the mean and Q2.5\% respectively Q97.5\% do (data are taken from [27]).

Schothorst et al. [30,31] conducted a similar study over 4 summer months in The Netherlands with respect to a possible increase in the risk of skin cancer in long-term UV-B radiation treated psoriatic patients. PE was measured in individuals with indoor and with outdoor occupations. The annual PE was estimated using climatological values of solar radiation (indoor: 220 standard erythema dose (SED), outdoor 480 SED, therapy: 810 SED, whereas 1 SED is equivalent to an erythemally weighted radiant exposure of $100 \mathrm{Jery} / \mathrm{m}^{2}$ [32]. Applying the risk formula of Fears et al. [14], a risk increase of a factor 2.5 to 7.5 was found for patients that receive this incredibly high UV radiant exposure from therapy.

Until this date, PE was measured at the lapel site. However, there may be other body parts, which are more exposed to UVR than the chest. According to this, Holman et al. [33] conducted a study focusing on the body distribution of PE during occupation (classroom teacher, physical education teacher, gardener, roof carpenter and bricklayer) and during leisure time activities in Perth $\left(32^{\circ} \mathrm{S}\right)$, Western Australia between June and October. The volunteers were equipped with six PSF badges attached to: vertex, lower sternum, lumber spine, shoulder, upper arm, dorsum of hand (unfortunately not on the lapel site). The ERTA was derived by comparison to ambient UVR measured by PSF, as well. This showed that the ratio of PE at different body sides changes with activity. The ERTA values gained by Holman et al. are relatively high, which may be attributed to less cloudiness, so that the direct beam significantly contributed to PE. Furthermore, they attached PSF at the same positions on a rotating manikin and compared the exposure with individual PE. They drew the important conclusion that measurements on a manikin do not deliver appropriate values, because some body parts, such as shoulders, can receive more UVR during different postures and movement, while other anatomical sites, for instance the upper arm, can receive less.

Until 1987, several action spectra for erythema in human skin were derived, which differed slightly from one another [34]. In 1987, McKinlay and Diffey [35,36] compiled a reference action spectrum, expressed as a mathematical formula, based on most reliable available data. This action spectrum was accepted as a standard by several international organizations. Since its introduction, measurements as well as calculations of the erythemally effective UVR have become comparable. However, a slight inattention during writing the formula into a standard paper in 1998 [32] resulted in a small but noticeable difference, especially when used to weight solar spectra [37]. Since then, the CIE (Commission Internationale de l'Eclairage) action spectrum from 1998 [32] has been used as the reference 
action spectrum for erythema. This action spectrum has also been used as a general proxy for other detrimental effects, which are mainly induced by UV-B radiation.

Apart from the skin, eyes are also a major target for detrimental effects from chronic UV exposure. Therefore, Rosenthal et al. [38] focused on the ocular UV exposure of three different groups of outdoor workers and the reduction by the use of hats. Prior the field campaign, they identified the most appropriate position as a proxy for the eye. For this, they used manikins with and without a hat and found the bridge of the nose to be the most appropriate position for both setups. Measurements were carried out in the region of Baltimore, USA, including seafood fishermen (March to November), a group of landscape workers and gardeners (July) and a group of carpenters (July). In July, carpenters had the highest ERTA (8.4\%), followed by fishers (6.3\%) and ground staff $(4.6 \%)$. For the fishermen, the ERTA is highest when the sun is lower (March and November, $17 \%$ ), and lowest when the sun is highest. Analysis of data made clear that the influence of reflectivity on ocular PE (and ERTA) is higher for water than for grass, and that the contribution of reflectivity is highest at medium solar elevations. A certain reduction of PE by hats (factor 1.5 to 2 ) as well as by canopies on boats was found. Later on, Diffey and Cheesman [39] investigated protective ability against the sun of 28 different hat forms in detail.

Milestones:

- $\quad$ Discovery of the suitability of PSF as chemical personal UV radiant exposure meter [18]

- Calibration of PSF in respect to the erythema response on a daily base to natural solar UVR [19].

- Introduction of the exposure ratio to ambient UVR (ERTA) [19].

- $\quad$ ERTA changes differently to PE with solar elevation, time of the year, etc. [24].

- ERTA derived from measurements on longer time intervals (e.g., weeks) is hardly influenced by cloudiness while PE is influenced [23].

- $\quad$ ERTA differs with activity [24].

- The ratio of ERTAs (and that of PEs) between different body sites is not constant [23,33].

- PE from manikins is not a surrogate for that of moving humans [33].

- Differentiation (e.g., analysis of personal exposure) between: Indoor, mixed-indooroutdoor and outdoor activities [28].

- $\quad$ PE on weekends and holidays differs from that on working days. Both contribute significantly to total PE [19].

- $\quad$ PE from phototherapy is critical and must be monitored [28-31].

- Frequency distribution of PE in a subpopulation has positive skewness and needs appropriate statistical parameters for description (median, skewness, percentiles, etc.) [29].

- Division into PE between: essential duties of everyday life (shopping, travel to work, etc.), recreation and holiday activities (skiing, hiking, etc.), phototherapy (if applicable) and from occupation [24,28].

- Introduction of activity diaries [26].

- Noticeable contribution to PE can come from natural surface reflection (albedo) and from reflectivity of artificial surfaces [38].

- Definition of a reference action spectrum for erythema $[35,36]$.

\subsection{The 1990s}

UVR studies in the 1990s were widely prompted by the concern on detrimental effects from enhanced environmental UVR [40] as a possible consequence of the Antarctic ozone hole [41] and the ongoing observed stratospheric ozone depletion at middle latitudes [42].

Concern had arisen that pilots could be overexposed to UVR during their cruises at lower stratospheric altitudes, above the clouds. To estimate the potential risk of this targeted population, Diffey and Roscoe [43] equipped pilots and flight crew with PSF, which were fixed on the epaulette (of the jacket or shirt) facing the window. None of the flights, although all lasted several hours, resulted in a higher PE of the in-flight staff than that received from a few minutes outdoors. 
To make use of the available ERTAs and to estimate ocular exposure over a longer period, Rosenthal et al. [44] developed a first numerical model. The model runs on a monthly base by taking into account ambient UVR, different activities (ERTA, time and duration, activity index with an hourly resolution) and a conversion factor from PE to ocular exposure. Diffey [45] presented a similar model that works on a weekly basis. Contrary to nowadays [46], at this time, ambient UVR was not operationally measured at many places (e.g., [47]) and, therefore, UVR data was only scarcely available. A first climatology of the erythemally effective daily radiant exposure was provided based on measurements taken at stations which continuously monitored UVR on the northern hemisphere (e.g., [48]). These values could be used as model input to estimate PE. To overcome the former problem at that time and to obtain UVR values at any place and date, radiative transfer UVR models were developed (e.g., [49-52]). The accuracy of the model output depends mainly on the quality and availability of atmospheric input parameters, like total ozone, clouds or aerosols [53-57].

The knowledge and experiences gained from the pioneering studies on PE measurements were collected (e.g., [58,59]) and merged into a guideline for PE measurements, which was published by the CIE in 1992 [60].

Until that time, only PSF was used as UV sensitive material. In 1989, an alternative to PSF, based on allyl diglycol carbonate (CR-39), was presented [61]. Previously, CR-39 was applied as nuclear track detector. The badges had a diameter of only $1 \mathrm{~cm}$ and were many times smaller than the PSF mounting. This small size enabled researchers to place 117 of these on the head of a life-size manikin and to gain a highly resolved exposure pattern of the human head [62]. Additionally, indoor workers with different leisure activities wore the CR-39 badges on the wrist. Their PE showed large differences by a factor of 4-5, reaching the PE of outdoor workers (schoolteacher, security guard, equipment operator). PE of outdoor workers was also found to depend on leisure activity, however, not as strongly as for indoor workers.

Biological material reacts to UVR as well as polymer and hence can be used as biosensors for UVR. The advantage of the former is that the spectral response is related to the photobiological effect due to the biological material $[63,64]$. European projects like BWDSUVR [65] and BIODOS [66] delivered information on characteristics and potential of application. At the DLR (Deutsches Zentrum für Luft- und Raumfahrt) Quintern et al. [67] developed a biological PE meter to estimate the DNA damaging capacity of UVR. For this they used UV-sensitive spores of Bacillus subtilis (B. subtilis), which were immobilized in a biofilm. The idea originated from Munakata et al. [68], who used B. subtilis as a biological UV meter in Japan [69] to measure (daily) UV radiant exposure and later on at several locations around the globe [70-72]. Further development leads to the VioSpor badge (BioSense, Bornheim, Germany) [73] and the DLR-Biofilm [74]. Later it was shown that this meter could also be calibrated to measure the erythemally effective UVR [74,75].

Some years later, Galkin und Terenetskaya [76] presented a PE meter that enables measurement of the PE in respect to vitamin D photosynthesis. The biologically effective exposure is estimated from changes in the absorption spectrum due to the photoconversion of provitamin D to previtamin D. Unfortunately, no practical application was found in the literature search.

If results of a study depend strongly on the behaviour of participants, it is essential that participants do not change their behavioral patterns due to their participation (the so-called Hawthorne effect [77]. To control that, Herlihy et al. [78] introduced the use of a questionnaire to ask participants (of a campaign on weekend PE) about their sun behavior during the weekend before and the weekend of the study to guarantee that there was no change in behavior. Another strategy to avoid the Hawthorne effect is not to inform the participants about the purpose of attached sensor.

In 1992, scientists at Environment and Climate Change Canada created the UV Index as a tool to protect people from overexposure to the sun. A few years later this index was adopted by the WHO, World Meteorological Organization and the International 
Commission on Non-Ionizing Radiation Protection (ICNIRP) [79]. Today's UV index is a unit-less (open ended) quantity which is determined by the erythemally effective irradiance. For this, spectral irradiance is weighted by the action spectrum of human erythema (see Figure 3) (based on McKinlay and Diffey [35,36] in its current form according to CIE [32,80]) and normalized-after integration-to $0.025 \mathrm{~W}_{\text {ery }} \mathrm{m}^{-2}$ :

$\mathrm{s}_{\text {ery }}(\lambda)=1$ for $250 \mathrm{~nm} \leq \lambda \leq 298 \mathrm{~nm}$,

$\mathrm{s}_{\text {ery }}(\lambda)=10^{[0.094(298-\lambda)]}$ for $298 \mathrm{~nm}<\lambda \leq 328 \mathrm{~nm}$

$\mathrm{sery}_{\mathrm{ery}}(\lambda)=10^{[0.015(140-\lambda)]}$ for $328 \mathrm{~nm}<\lambda \leq 400 \mathrm{~nm}$

UV Index $=1 / \mathrm{k} \cdot 280 \int 400 \mathrm{~nm} \cdot \mathrm{E}(\lambda) \cdot \mathrm{s}(\lambda) \cdot \mathrm{d} \lambda$

$\mathrm{k}=0.025 \mathrm{~W}_{\text {ery }} \mathrm{m}^{-2}$

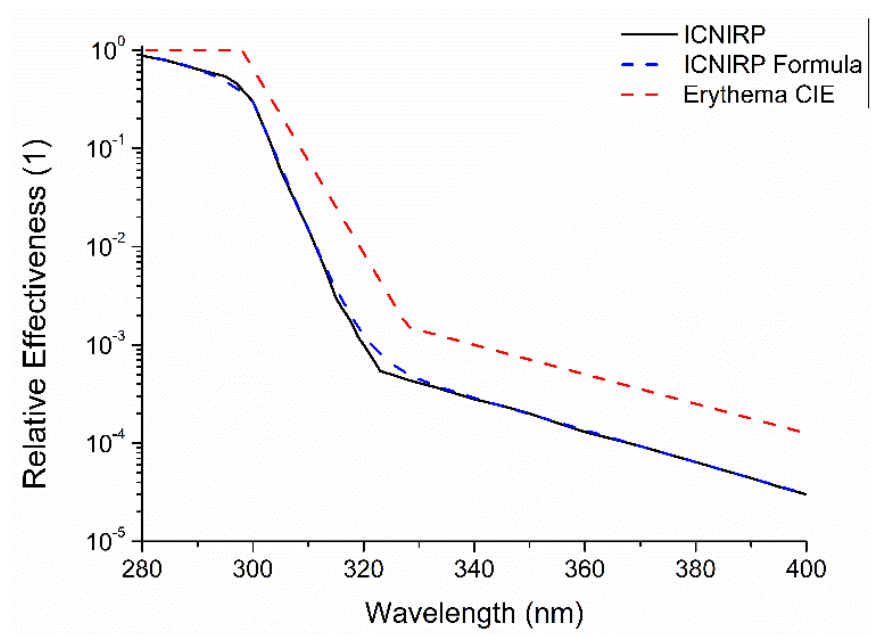

Figure 3. American Conference of Governmental Industrial Hygienists (ACGIH)/International Commission on Non-Ionizing Radiation Protection (ICNIRP) action spectrum according published tabled values [81]) (black line) and according the provided formula (blue dashed line) [82]. For comparison, the action spectrum of erythema according ISO (International Standards Organization) /CIE $[32,80]$ ) is shown (red dashed line).

The UV Index has become a widely used parameter to provide the level of potentially harmful UV radiation from the sun to the public [83,84].

Some years later, Gunnar Saxebol [85] proposed the concept of UV Index hours (UVIh) as a corresponding measure for the erythemally effective radiant exposure by integrating UV Index over time. With that, $1 \mathrm{UVIh}$ is equal to $90 \mathrm{Jery} / \mathrm{m}^{2}$ and is equal to 0.9 SED (for details see [86]). The SED was proposed [32], chronologically in between, in order to provide a quantity for the erythemally effective radiant exposure and to replace the misuse of the minimal erythemal dose (MED). 1 SED was set arbitrarily to be $100 \mathrm{Jery} / \mathrm{m}^{2}$.

Occupational UV exposure, especially from welding and later from other sources like lasers, was an early matter of concern and recommendations for threshold limit values have been proposed over the UV range (e.g., by the American Conference of Governmental Industrial Hygienists (ACGIH) $[87,88]$ ) and later by the International Radiation Protection Association (IRPA) [89]. In 1989, the International Non-Ionizing Radiation Committee of the International Radiation Protection IRPA/INIRC [90] (the precursor of the International Commission on Non-Ionizing Radiation Protection (ICNIRP) founded in 1992) revised the guidelines for wavelengths longer than $320 \mathrm{~nm}$ (which are valid until today). This threshold limit value (TLV) was set to $30 \mathrm{~J} / \mathrm{m}^{2}$ per working day $(8 \mathrm{~h})$ using the ACGIH action spectrum (see Figure 3 ) that considers both skin, as well as eye effects and differs, therefore, from the erythema action spectrum [32,80] (see Figure 3). This TLV corresponds to approximately 1.0 to $1.3 \mathrm{SED}$, when solar spectra are weighted with the erythemal action spectrum, respectively corresponds to an irradiance of 1 to $1.5 \mathrm{UV}$ Index received over $1 \mathrm{~h}$. When the UV Index is 7, this period is $10 \mathrm{~min}$. 
It should be noted that the description of the ACGIH/ICNIRP action spectrum by a mathematical function derived by Wester [89] and published in 2004 by INCIRP [90] does not fit the tabled values perfectly. Around the inflection points in particular, there are noticeable deviations (see Figure 3).

The Australian National Health and Medical Research Council [91] overtook this guideline and a comparison of the PE of outdoor workers and this TLV was undertaken for the first time by Gies et al. [92]. They equipped lifeguards, school ground staff (lawn mowing, edge trimming, etc.) and physical education teachers (PET) for 5 days with PSF badges on the chest and on the shoulder. The highest mean ERTA on the shoulder was experienced by the PET (median: $18 \%$, range: $1-33 \%$, mean: $19 \%$ ), followed by school ground staff $(15 \%, 8-48 \%, 18 \%)$, and lifeguards $(12 \%, 4-34 \%, 13 \%)$. On the chest, the lifeguards received most (3-32\%, 10\%), followed by PET (4-16\%, 8.5\%) and school ground staff $(4-26 \%, 8.2 \%)$. Therefore, the ranking of groups in respect to ERTA and PE differs by body site.

For the lifeguards the ERTA and PE depended on the usage of beach shelters, for the school ground staff on the time spent outdoor, and for the PET on the activity (e.g., swimming classes, sports on the playing fields). Analysis made evident that in all three groups PE exceeds the occupational TLV and that protective measures, including education and behaviour modification, are necessary to reduce PE.

The results clearly indicate the necessity of proper statistical descriptors, because the school ground staff did not experience the highest ERTA on average, but in some of them, the highest ERTAs were found. As UV exposure contributes exponentially to risk, these participants are at a noticeably higher risk than anybody else is (although they are not part of the highest exposed group).

Previous studies showed that PE of a person varies strongly with time. A radiant exposure meter (like PSF) delivers only one (cumulative) value for the whole period. Timeresolved monitoring of PE would require the periodical exchange of badges, which would result in the use of several badges and in an increase of data analysis. To overcome this problem, Diffey and Saunders [93] used a small attachable electronic sensor connected to a separate storage and display unit worn at the belt. Besides others, they measured PE received through an open car window during a journey with a temporal resolution of $2 \mathrm{~s}$. In respect to occupation, this could reflect the PE for professions implying driving like taxi drivers or deliverymen. The properties of this electronic device (spectral response, angular response, linearity) were well examined and taken into account for calibration. The disadvantages were especially the size and weight of the data logger. Later on, sensors became smaller and filters that mimic other spectral responses than erythema like pigmentation were introduced [94,95]. However, the prize, susceptibility to shaking and the size of the data logger prevented the application for occupational PE measurements (but became valuable in monitoring PE from therapeutic UVR sources). For outdoor use in a harsh environment like the Arctic, Naggar and colleagues [96] presented the prototype of an all-in-one miniature electronic device. This button-like, 3 channel (UV, visual, temperature) irradiance meter could measure with a temporal resolution of $1 \mathrm{~min}$ and could store 64,000 values. However, we could not find any application of this device in the literature.

One of the peculiarities of the study by Knuschke and Barth [97] was that they took into account the spectral change of solar radiation during its transmission through window glass [60] when calibrating the PSF badges. The study focused on a possible risk of vitamin $\mathrm{D}$ deficiency in indoor workers, housebound people and bedridden people. A large variability of PE in indoor workers (including recreational activities) was found. ERTA was lowest in autumn and highest in June. As an add-on, they presented data on the health damage risk in the face of welders and non-welders around arc welding workplaces. Even PE of the latter exceeded the TLV due to stray light radiation.

A pilot study with women in home duties was undertaken [98] at two close locations in Australia (Brisbane and Toowoomba; distance: $127 \mathrm{~km}$ ) to investigate the influence of 
altitude $(700 \mathrm{~m})$ on PE. There was a tendency that women at higher altitude receive higher $\mathrm{PE}$, but due to the study design (only one day lasting, differences in weather, climatic conditions, small cohort, differences in attitude) no definite conclusions could be drawn. In general, the relative increase of UV-B with altitude is around 19\%/1000 m (e.g., [99]). However, even a difference in altitude of $1500 \mathrm{~m}$ (for a distance of approximately $200 \mathrm{~km}$ ) becomes visible in daily UV radiant exposure only if longer periods are analyzed [100]. Differences in meteorological conditions like cloudiness may inhibit the enhancement being found even in summer. The study [101] was expanded by a few days, including outdoor workers (lawn mowing contractors) and schoolchildren. Interestingly, when being outside, the homeworkers received more UVR than the outdoor workers and therefore had a different PE pattern. Further analysis [102] showed that home workers received higher PE on the weekends, than outdoor workers did. ERTA for all was highest on the neck, followed by the hands and left arm. Another interesting finding was that the ERTA was higher in winter (July) than in November and February. This study confirmed the findings by Diffey et al. [103] that activity, behavior and attitudes within a target population are as important as ambient UVR is.

In many countries, daylight saving time was reintroduced in the late 1970s and early 1980s during the energy crisis. Setting clocks forward by one hour results in a shift of maximum irradiance to around 13:00 and in a prolonged daylight in the evening. In 1999, Parisi et al. [104] investigated the influence of the daylight saving time on the occupational exposure in Australia using the model of Rosenthal et al. [44] and Diffey [45]. It was found that PE can become enhanced or reduced due to the time shift depending on the working hours and on the time of the breaks (e.g., mealtime, tea breaks). A general conclusion could not be drawn.

Milestones:

- Guidelines for PE measurements [60].

- Alternatives to PSF from plastics [62].

- Usage of biological materials for badges $[63,76]$.

- First developments of electronic personal irradiance meters [93].

- Avoidance of the Hawthorne effect [78].

- Exposure models using ERTAs [44,45].

- Comparison of PE with threshold limits according guidelines on limits of exposure [92].

- $\quad$ ERTA is not necessarily highest in summer and lowest in winter [97].

- There is a tendency that PE of outdoor workers on weekends is lower than those of non-outdoor workers [101].

- Work flow (e.g., timing, etc.), activity, behavior and attitudes play a key role for PE [102].

\subsection{The $2000 \mathrm{~s}$}

PSF badges, as any other broadband meter, need a proper calibration in respect to the spectral response (of PSF as well as of the biological effect), linearity and others. Calibration factor depends mainly on total ozone, solar elevation and the radiant exposure that is absorbed by PSF. All these parameters change with time. A variety of studies in the 2000s focused on this topic (e.g., [105-108]). Figure 4 visualizes the correction factor for PSF spectral response and the action spectrum of erythema [32] and vitamin D photosynthesis [109] dependent on total ozone column and solar elevation. 
(a)

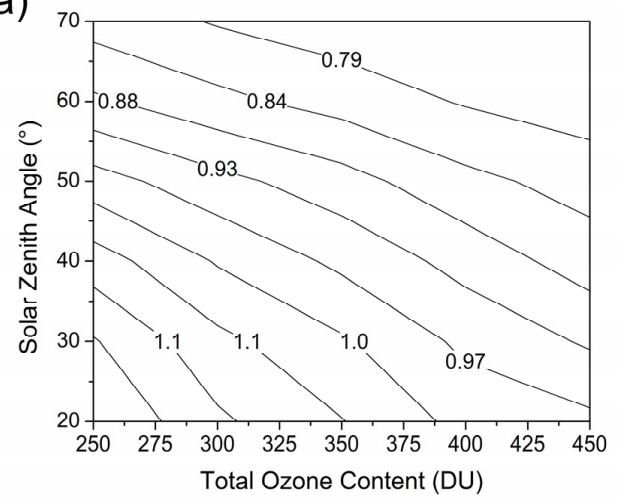

(b)

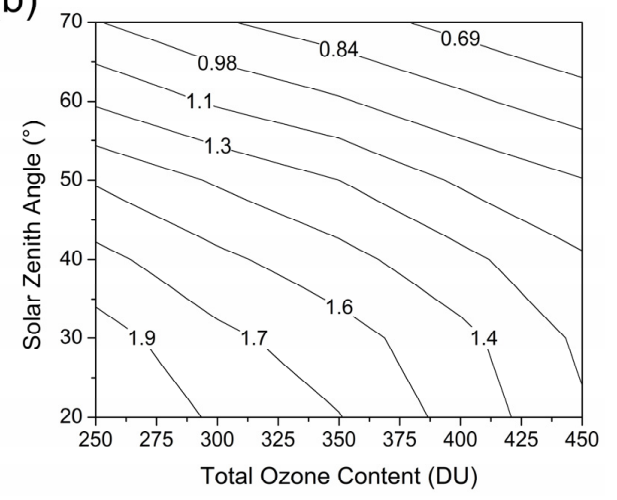

Figure 4. Examples for correction factors (calibration matrix) for polysulphone film (PSF) to gain erythemally effective radiant exposure (panel (a)) or vitamin D effective radiant exposure (panel (b)) (after [101]).

Moehrle and colleagues $[110,111]$ were the first to report testing the spore film meter type VioSpor (B. subtilis spore) by equipping lifeguards, skiing instructors, mountain guides and schoolchildren with these badges. They reported their experiences and a good performance of this PE meter. The PE of ski instructors and mountain guides was only expressed in MED (i.e., minimal erythema dose, equivalent to the amount of UV radiant exposure that will produce minimal erythema within a few hours after exposure). In this study, 1 MED was assumed as $250 \mathrm{~J} / \mathrm{m}^{2}$. For a single day, the ERTA on the shoulder of the lifeguards was estimated to be $55 \%$ on average. In a second study [112], nine mountain guides wore VioSpor badges for a year. The presented monthly mean PE of each mountain guide ranged up to 24 SED per working day. The annual PE was within 331 SED and 1770 SED.

Meanwhile, other continuous measurements (with VioSpor), lasting over several months, were presented in 2001 by Thieden et al. [113]. They collected measurements from 39 indoor workers in Copenhagen using a VioSpor meter mounted at the wrist between late June and mid September. Before that, the reliability of the wrist for body exposure was proven [114]. Thieden et al. found that indoor workers receive around $4 \%$ of ambient (including weekends) UVR and that they receive 20\% during domestic holidays and around $45 \%$ (of domestic ambient) when going for holiday to southern Europe. These ERTAs were extracted from a comparison to ambient UVR, which was measured with a broadband meter at Copenhagen.

The first PE campaign that lasted longer than 1 year was conducted by Vishvakaraman et al. [115]. Australian post mail delivery personnel (on a motor cycle, equipped with PSF at 3 body sites) and physical education teachers (equipped with PSF at 5 body sites) from Rockhampton, Australia $\left(23.5^{\circ} \mathrm{S}\right)$ participated in this study. Monthly mean PE for each group covering the 18-month period from April 1994 to September 1995 for all body sites were calculated and only one ERTA for each group for the entire period. The physical education teacher had the highest PE. The mail carriers had approximately $70 \%$ of that. In both groups, TLV was always exceeded.

The PE of 30 arctic field scientists was evaluated by Cockell et al. [116] during July in a project to use a polar crater as a Mars analogue site. The Haughton impact structure is a meteor-formed impact basin on Devon Island in the Canadian Arctic Archipelago $\left(75^{\circ} \mathrm{N}, 89^{\circ} \mathrm{W}\right)$. A small size electronic personal irradiance meter (X-2000, Gigahertz-Optik, Puchheim, Germany) was used as well as DLR Biofilm badges using B. subtilis. The former was calibrated by comparison with a calibrated spectroradiometer in Germany prior to the study. The electronic meters were also used to measure erythemal weighted irradiances at different orientations. PE during different field activities was measured. ERTAs were determined for a variety of activities were in the range from $11 \%$ to $52 \%$. For those who were working under a tent, the ERTA was half. ERTAs were highest for short 
intervals and clear sky and lowest for longer intervals and high cloud cover. The highest UV radiant exposure within one hour was 1.1 SED. One year later Cockell et al. [117] published PE measurements collected at the Antarctic Rothera station $\left(67^{\circ} \mathrm{S}\right)$ in December, when the highest solar elevation was $45^{\circ}$ under varying weather conditions. Volunteers were equipped with X-2000 and DLR Biofilm badges. ERTAs showed a similar variability (3-40\%) to that found in the Arctic.

Gies and Wright [118] performed a study measuring the PE of almost 500 workers (divided into 19 occupational groups) in the building and construction industry at 107 building sites in Queensland (Australia). Each participant wore the PSF badge for $4 \mathrm{~h}$. Ambient UVR measurements were taken from the closest station of the ARPANSA (Australian Radiation Protection and Nuclear Safety Agency) network [119]. The authors pointed out that the frequency distribution of participants PE and ERTA can be represented by Poissonian-like distributions. PE of $90 \%$ of all workers exceeded the TLV within the 4-h period. Additionally, PE was partly in excess of ambient UVR (ERTA $>100 \%$ ) because of working in the open and on highly reflective surfaces (pavers, tilers, roofers etc.).

At the beginning of the millennium, Thieden et al. [120] started a large campaign on PE of the Danish population including children, adolescents, indoor workers, golfers and gardeners. Analyses of data were published in several papers with respect to the compliance of diaries [121], to age [122], occurrence of sunburn [123] and sunscreen use [124]. For this study, a miniature electronic personal irradiance meter type called "SunSaver" (possessing a SiC photodiode as UVR sensor) was designed [125,126], that can be worn like a wristwatch (see Figure 5). A group of participants considering themselves as "sun worshippers" or "sun seekers" was identified. Although this group did not have the highest median PE, the lowest and the highest PE in this group were both higher than those of any other group involved in the campaign. Additionally, Thieden et al. [120] introduced a threshold of 10 SED as a measure for risk. The value of 10 SED comes with the assumption that people with skin type II $\left(\mathrm{MED}=250 \mathrm{~J} / \mathrm{m}^{2}=2.5 \mathrm{SED}\right)$ according to Fitzpatrick [127] can be sunburned on adopted skin by this radiant exposure (increase in the melanin content of the skin and its thickening equivalent to a self-protection factor 4). The analysis showed that golfers, gardeners and indoor workers are at a similar risk. The risk of the sun worshippers is at least $50 \%$ higher. However, the highest risk behavior was found in adolescents. Thieden et al. showed that the ERTA (of the whole population) changes during the year (April-October) on working days and on days off with slight differences by group. In total, indoor workers received around $4.0 \%$ during this period, sun worshipper $6.1 \%$, gardeners $6.6 \%$ and the golfers $7.5 \%$ (including working days and days off). It was shown [123] that sunburn occurred mostly on days off work and that children, golfers and gardeners had the lowest number of sunburns. On the other hand, the use of sunscreen [124] was the lowest by golfers and gardeners. PE of indoor workers and gardeners does not differ between genders [120].

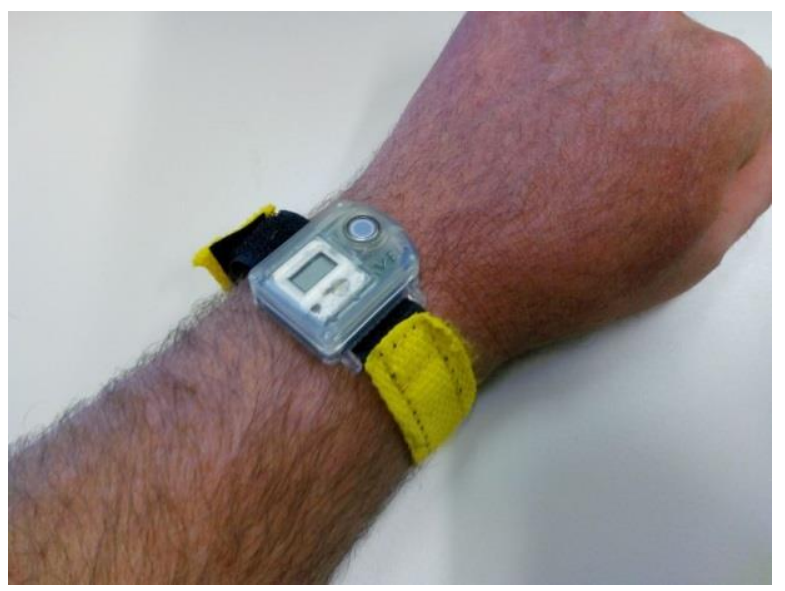

Figure 5. Miniature electronic personal irradiance meter of type SunSaver. 
Hereinafter, Thieden et al. [128] measured the PE of 31 gardeners in Dublin $\left(53^{\circ} \mathrm{N}\right.$ Ireland) and of 22 gardeners in Copenhagen ( $55^{\circ} \mathrm{N}$, Denmark) during June, July and August distinguishing between working days and days off. Gardeners wore a SunSaver like a wristwatch. Ambient UVR was measured with a broadband meter (Copenhagen) and a SunSaver (Dublin). On working days, the Danish gardeners received around $8 \%$ of ambient UVR, the Irish $6 \%$ and, respectively $6 \%$ and $3 \%$ during days off.

In 2006 Thieden et al. [129] published another PE study on a group of indoor workers wearing a SunSaver on the wrist. It was shown that the ERTA in winter was $1 \%$, while in summer it was 3.4\%, mainly caused by being less time outdoors in winter (length of the day). Holidays in southern destination were again found to contribute substantially to the PE of Danes.

In a short report by Weber et al. [130], the PE on the neck and chest of outdoor tinsmiths on building sites (roofing) was presented. Generally, the typical workplace situation for outdoor tinsmiths involves working with highly reflective materials, which can contribute significantly to PE [131]. The study involved 14 workers being equipped with PSF badges in the province of Carinthia, Austria $\left(46^{\circ} \mathrm{N}, 500 \mathrm{~m}\right.$ a.s.l.), during June and July. ERTA was determined, taking into account the ambient UVR provided by a station of the Austrian UVR network [132,133]. An ERTA of 50\% for the neck and of $12 \%$ for the chest was found. This study was part of a larger project that included the examination of the acceptance and usability of personal protective measures against solar UVR [134]). At this time, different types of photochromic card for indications of solar UVR were in circulation as a cheap and easy device to provide PE (see Figure 6) during occupation or leisure time. These cards indicate PE by changing colors, depending on absorbed UVR exposure. However, it was found that these cards did not give an appropriate estimation of the erythemally effective UVR due to their spectral sensitivity and their sensitivity to temperature [135].
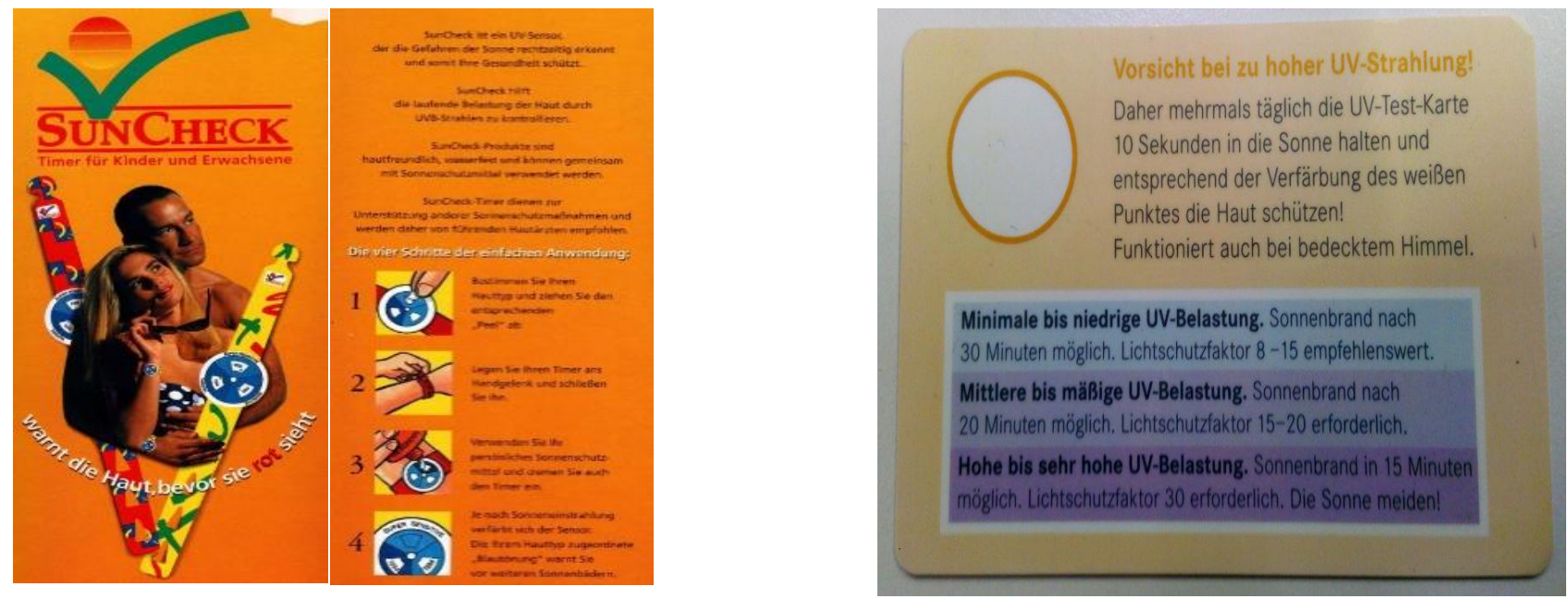

Figure 6. Examples of indicator cards (photochromic) from the 1980s and 1990s worn like a wristwatch (left) or designed like a credit card.

Another study in the alpine region was performed by Milon et al. [136] who involved building workers at different altitudes in the alpine environment. For the assessment of PE, working activities at three different altitudes were investigated: at 500-600 m (foundation building of cable car pylons in plain), 1400-1500 m (roofers) and 2000-2500 m (foundation building of cable car pylons in high mountains). PE was measured with VioSpor badges on five body sites on 10 sunny days (excluding midday break) between July and September. ERTAs higher than $100 \%$ were measured on the forehead, neck and shoulder. Daily PE ranged from a few SED up to 80 SED. Each worker had an observer by his side who recorded the postures and the orientation in respect to the sun. A detailed exposure model 
was developed to calculate PE from posture, orientation and ambient UVR. Posture and orientation were found to contribute more to PE than altitude.

Another group working in alpine regions are skiing instructors. High albedo and high altitude together with high solar elevation result in extremely high UV exposure $[137,138]$ that can be even enhanced in the presence of broken clouds, with respect to clear sky (e.g., [139]). The study by Siani et al. [140] on the PE on a high altitude ski field $\left(46^{\circ} \mathrm{N}\right.$, $2100 \mathrm{~m}$ a.s.l.) provided two additional novelties: measurements of skin color (expressed in $L^{*} a^{*} b^{*}$ tristimulus system according the CIE 1976 definition [141]) prior to and after exposure, and the introduction of the UV Index in PE estimates. The UV Index was already introduced in 1995 [79], under the involvement of ICNIRP, to provide an easily understandable parameter of the erythemally effective UVR $[83,84]$. However, it needed more than 10 years until the UV Index was applied in PE measurements. For this, the daily course of irradiance was expressed in units of the UV Index. This directly connects PE and the proposed tools for sun protection in dependence of the UV Index $[83,84]$. In the study of Siani et al. [140], skiing instructors and skiers were equipped with PSF on the forehead (see Figure 7) and the campaign was carried out in winter and in spring. PSF badges were exchanged periodically between 10:00 to 16:00 to prevent saturation of PS due to the high UVR levels at that altitude. With this periodic exchange, ERTAs higher than $100 \%$ over $1 \mathrm{~h}$ could be measured. Additionally, temporarily resolved ERTAs could be derived, which led finally to a complete ERTA-model for UV exposure of the face up to solar elevations of $63^{\circ}$ [10]. Later, PE of skiers at the nearby Plateau Rosa $\left(46^{\circ} \mathrm{N}, 3500 \mathrm{~m}\right)$ using PSF and poly-dimethyl phenylene oxide film (PPO) was investigated [142].

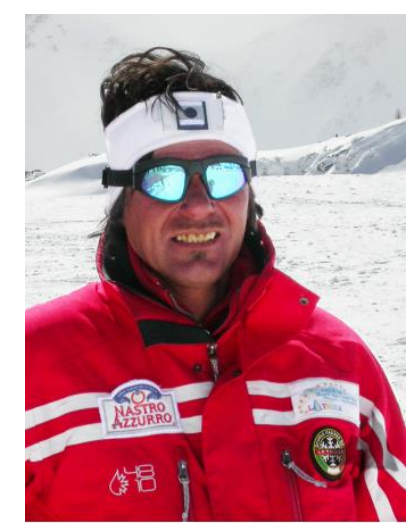

Figure 7. Skiing instructor at La Thuile-Les Suches ski field $\left(45.7^{\circ} \mathrm{N}, 6.6^{\circ} \mathrm{E}, 2100 \mathrm{~m}\right.$ a.s.l.), wearing PSF badge at the headband [140].

Ice and snow possess high reflectivity. Sunburn in Antarctica was recognized in $70 \%$ of expeditioners during a PE field campaign by Gies et al. [143]. PE of around 200 expeditioners was measured during 5 unloads of resupply vessels (6-14 h) at 3 different Australian Antarctic stations (Casey, Davis and Mawson). The UV Index was up to 7 and cloud cover ranged from 5 to 7 octas. Expeditioners wore a PSF badge on the chest. Measured PE was up to 19 SED, which corresponds to an ERTA of 50\%. The median was found at an ERTA of 10\% (3 SED).

Surveys or questionnaires and sun habit diaries could be cheap means to estimate people's PE without measurements and would, therefore, be applicable to very large cohorts. However, the reliability, especially for recollecting past behavior, is debatable. In a pilot study, O'Riodan et al. [144] validated a sun exposure diary and a questionnaire by objective measurements. Seven lifeguards as well as parents and children participated in this study spending time at a swimming pool in Honolulu, Hawaii $\left(21^{\circ} \mathrm{N}\right)$ between 9:00 and 16:00 on 4 days in September. They were equipped with a PSF wrist badge. PSF badges measured ambient UV radiant exposure of around 37 SED. The lifeguards used an umbrella 
as a means of sun protection but still received $28 \%$ (median) of ambient. The self-reported sun exposure diaries agreed significantly better with measured PE than questionnaires did.

The PE of four gardeners and five lifeguards was measured in the region of Valencia $\left(39^{\circ} \mathrm{N}\right)$, Spain by using VioSpor badges worn at the wrist. Serrano et al. [145] reported that the gardeners received 3.3 to 4.6 SED during the $7 \mathrm{~h}$ work shift (6:00-13:00) on 5 days in June. This resulted in an ERTA of $7 \%$ to $10 \%$, with respect to the ambient UVR of 47 to 49 SED measured by a collocated broadband meter during the same period. For the lifeguards at the beach, the PE was measured for 6 days in July from 10:00 to 19:30. Daily ambient UV radiant exposure (broadband meter) was around 43 SED over $9.5 \mathrm{~h}$, while the lifeguards received 9 to 14 SED per workday. ERTAs ranged from $21 \%$ to $33 \%$.

Lifeguards across the USA wore a PSF on the wrist in a study designed by Gies et al. [146]. In total, PE of 168 individuals from 16 pools over two days (8:00-16:00) were measured in June and July in Austin $\left(30^{\circ} \mathrm{N}\right)$, Phoenix $\left(33^{\circ} \mathrm{N}\right)$, Omaha $\left(41^{\circ} \mathrm{N}\right)$ and Portland $\left(45^{\circ} \mathrm{N}\right)$. Proper ERTAs for the wrist were derived: 12\% (interquartile range (IQR): $4.0-22 \%$ ), 18\% (4.4-37\%), 29\% (13-37\%) and 12\% (6.4-22\%). PE of lifeguards was compared to the TLV according ACGIH-ICNRIP and to the MED for fair skin (= 2 SED). Observations of protection behavior brought to light: $82 \%$ of individuals taking part to the study used sunglasses, $50 \%$ used sunscreens, $16 \%$ wore a hat, 15 a shirt with long sleeves and $17 \%$ sought shade. During this study (parents and children were included as well), the validity of self-reported solar UV exposure was proven by a comparison with the measured PE [147] and was rated fair to good.

In New Zealand ( $45^{\circ} \mathrm{S}$, Central Otago), three different groups of outdoor workers were studied by Hammond et al. [148]. In total, 77 workers at 13 locations wore electronic irradiance meter (possessing an AlGaN sensor) $[149,150]$ ) for 5 consecutive working days (10-16:00) on the rear collarbone. The electronic meters were calibrated against a RoberstonBerger meter before the study. During the 7-week (January to March) campaign, the ERTA of builders (including roofers) was $19.6 \%$ (min.-max.: 1.6-66.4\%), that of the horticulture workers (including viticulture) which was $24.0 \%(1.4-81 \%)$ and that of the road workers (including paving) was $20.5 \%(1.4-83 \%)$.

Milestones:

- $\quad$ PE measurements lasting a year and longer [112,115].

- Calibration of PSF in dependence of solar elevation and total ozone [105-108].

- Introduction of the UV Index into PE measurements [140].

- $\quad$ Connection of PE and biomarkers (skin color measurements) [140].

- Definition of "sun seekers" [120].

- Analysis in respect to a self-protection factor of 4 for sun adapted skin [120].

- $\quad$ ERTA larger than $100 \%$ was reported [140].

- Usage of electronic personal UV irradiance meter [120].

- Indicator cards do not provide reliable measurements [135].

\subsection{The 2010s}

In the 2000s, a variety of studies was performed using electronic irradiance meter. However, less attention was given to the proper calibration of these devices as well as on the influencing factors. In most electronic devices sensitivity to temperature and deviations from linearity are rarely problems, but both properties have to be checked. Dark current is trivial to handle, but a certain degree of uncertainties remains from an imperfect cosine-like angular response [27]. Very critical is the mismatch between the spectral response of the device and that of the biological effect. The corresponding correction factor changes as the solar spectrum changes. The shape of the solar spectrum depends on the first order of total ozone, solar elevation and altitude. For similar altitudes, a calibration matrix, which accounts for changes in total ozone and solar elevation, ensures accurate measurements [27]. Figure 8 shows an example of a 2-channel (UVB and UVA) electronic personal irradiance meter type X-2000-10 (panel a) together with its spectral response (panel b) in comparison 
to the action spectrum of the erythema [32]. The calibration matrices for each channel to gain erythema weighted irradiance are shown as well (panels c,d).
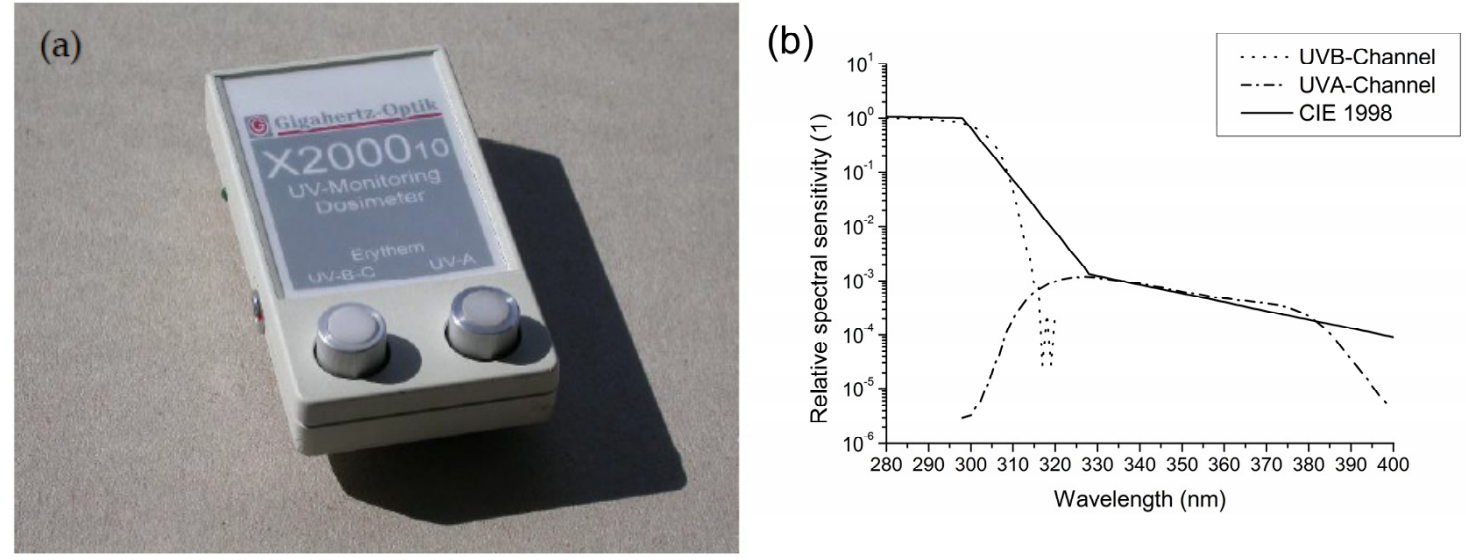

(c)
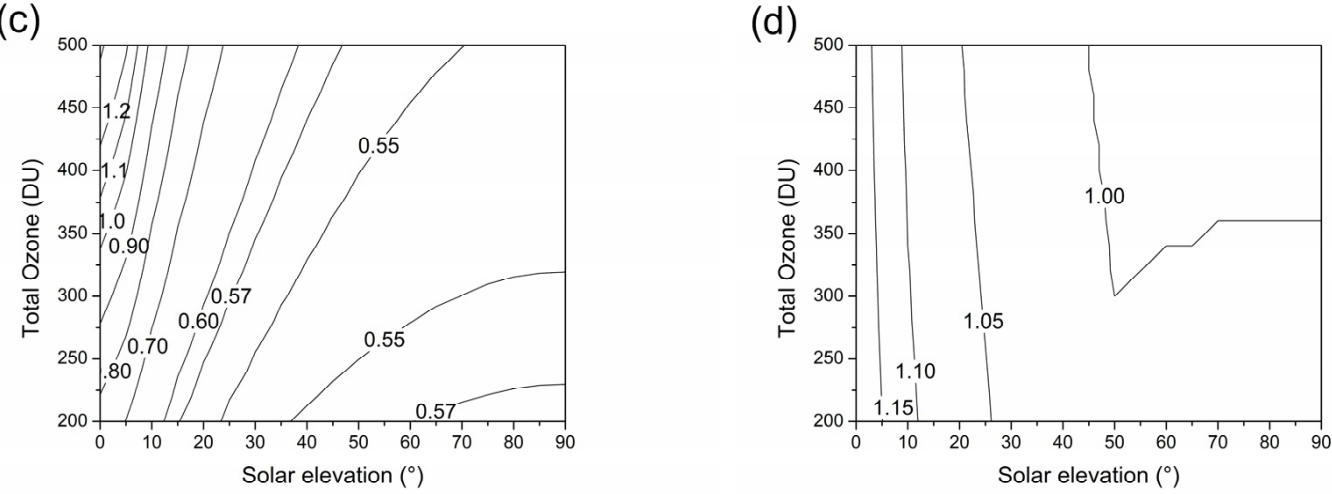

Figure 8. (a) 2-Channel personal irradiance meter. (b) spectral response of UV-B and UV-A channels compared to the erythema action spectrum [32]. (c) visualization of the calibration matrix (solar elevation and total ozone) for the UV-B channel and (d) for the UV-A channel to gain the erythemally effective UV irradiance (according [27]).

An important area of outdoor occupations is agriculture. The skin of farmers and seafarers was recognized early as being different from that of people involved in other professions [3]. The PE of Austrian farmers was investigated by Schmalwieser et al. [27], using an electronic irradiance meter (X-2000-10, see Figure 8) mounted on the forehead of 12 participants (see Figure 9). Participants filled in a diary including weather, posture, shadow, clothing, altitude and activity on an hourly base (see Figure 1) from April to October. The total PE of farmers showed high variability and ranged from 77 to 757 SED. PE correlated with the number of working days and with days of high risk (PE > 10 SED). Besides working in an unshaded environment, several other risk factors could be identified, such as working on mixed-culture farms with aggravated working conditions, a low degree of automatization, load of manual work outdoors, driving machines without cabin and, interestingly, female gender. Females had higher number of risk days, caused by performing different working tasks than male farmers. A simple exposure model using the number of working days, number of days with high risk and gender could describe the UV radiant exposure quite well. Other issues of the study were medical examinations of the eyes and the skin of 500 farmers and of a control group of 100 indoor workers. In the investigated group ( $<60$ years), no significant difference in the frequency of UVRinduced skin tumors could be found. Photoaging and UVR-induced eye lesions [151] were pronounced more in farmers, than in the control group. Sun protection measures (e.g., sun crèmes) were not very well-liked by farmers and were used mainly for other reasons (e.g., long sleeves for protection from dirt and dust), if necessary [152]. 

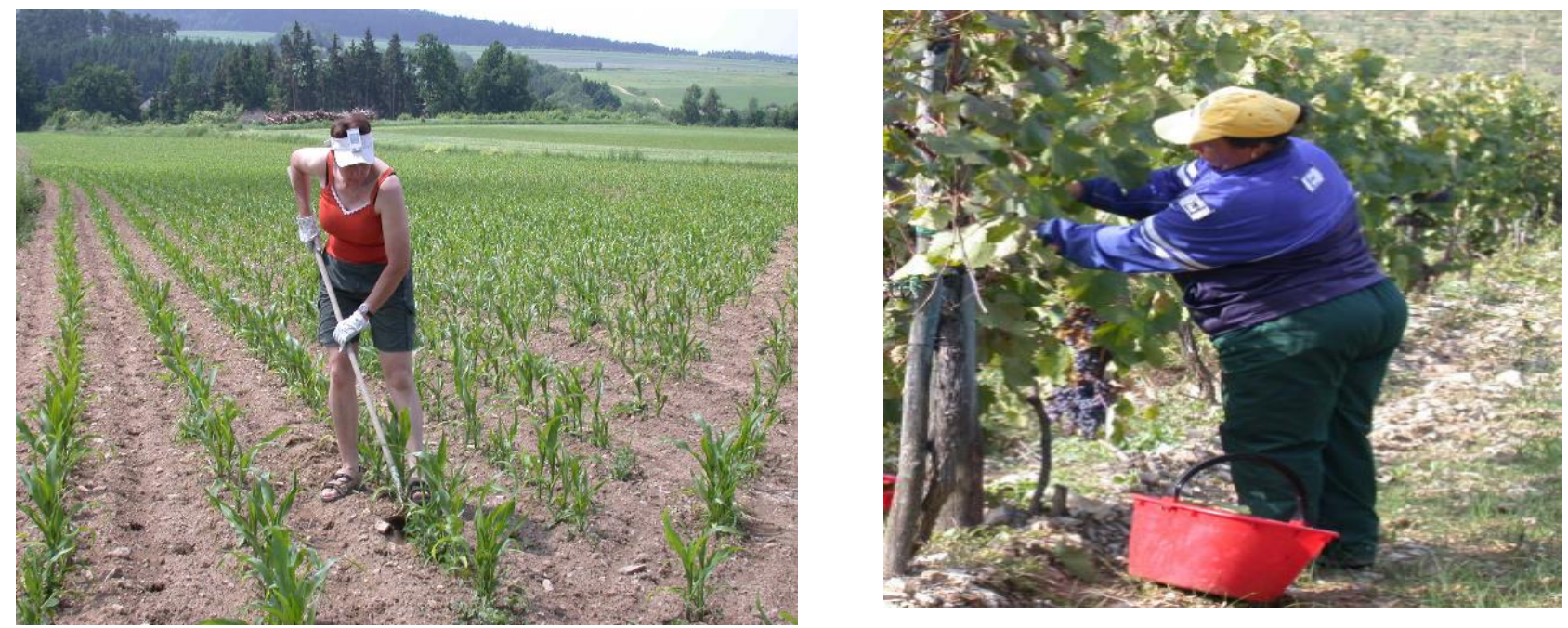

Figure 9. Exposure ratio to ambient UV radiation (ERTA) exceeding a value of $100 \%$ due to monotonic workflow. Left: Austrian farmer (organic farming, mixed-culture) during weeding, wearing an electronic personal solar UVR exposure (PE) meter mounted on the forehead [27]. Right: Italian vineyard worker during harvest equipped with two PSF badges (one on the back one on the arm) [153].

Contrary to the alternating workflow of the mixed-culture farmers (most frequent type of farming in Austria, from above) is that of the highly specialized winegrowers. Siani et al. [153] quantified the PE of 32 vineyard workers in the Tuscany (Siena, $43^{\circ} \mathrm{N}$, $300 \mathrm{~m}$ a.s.1.), Italy, adhering PSF on the back and on the arm (see Figure 9). Their activities covered three different work stages in a vineyard (April: preparation, July: grape pruning and soil fertilization October: harvest). ERTA differed significantly across the two anatomical sites within each season: The back was most exposed mainly in spring (ERTA ranges from $53 \%$ to $87 \%$ ). The high ERTA can be explained by a generally bent-forward posture, often averted from the sun. A PE of 10 SED was exceeded on the back and arm in April and July. Additionally, skin colour of the cheek was measured prior and post PE measurements. Changes of skin colour during 2 days of exposure were significant only in April. This [146] and the former study [27] showed that during a monotonic workflow, the ERTA can exceed $100 \%$ for a noticeably lengthy time duration.

Another study on specialized outdoor workers (steel fixer, farmworker, foreman, security officer) was undertaken by Serrano et al. [154]. The study location was Valencia, Spain $\left(0^{\circ} 23^{\prime} \mathrm{W}, 39^{\circ} \mathrm{N}, 0 \mathrm{~m}\right.$ a.s.l.). The workers wore a VioSpor badge on the shoulders or on the chest. The PE of 8 construction workers over 5 days in July, from 8:00 to 19:00, was evaluated. The highest PE was found for the steel fixer (ERTA median $42 \%$, chest) followed by farmworkers (17\%, chest or shoulder), foreman (13\% chest) and security officers ( $14 \%$ shoulder).

Beside the farmers, the other early-recognized group having apparent sun adapted skin is the seafarers. Feister et al. $[155,156]$ measured PE of seafarers along subtropical and tropical shipping routes (the Atlantic, the Caribbean, the Mediterranean and the Indian Ocean) for durations between 1 and 3 weeks. They collected data from 61 days along four routes of merchant vessels using VioSpor badges which were clipped on the head, the shoulder, the chest and the back [155]. Badges were exchanged daily, whereas daily working time was $8 \mathrm{~h}$. Overall, ERTAs ranging from $32 \%$ to $46 \%$ for the head, from $22 \%$ to $33 \%$ for the shoulders, and from $11 \%$ to $20 \%$ for the chest and back, were found. ERTAs were calculated with respect to clear sky model calculations. The average $8 \mathrm{~h}$ radiant exposures received on the head during the first two voyages was 19.1 SED, and 26.9 SED for the third and fourth voyage. The ambient UVR measured on board was up to $19 \mathrm{UVI}$ and up to 22 UVI for short periods during broken cloud conditions. The maximum daily $\mathrm{UV}$ radiant exposure reached $95 \mathrm{SED}$. 
Another extreme environment was investigated in 2013 by Cheng et al. [157]. They equipped 15 expeditioners and 10 Sherpas with VioSpor badges set on the top of the head. The climbing expedition at the north side of Mt. Everest $(8848 \mathrm{~m})$ started in late April and lasted until the beginning of June. The Sherpas did ascents of Lhakpa Ri (elevation: $7045 \mathrm{~m}$ a.s.1., on 9 May) and two times of Mt. Everest (elevation: $8848 \mathrm{~m}$ a.s.l., on 22 May and 4 June). Their cumulative UV radiant exposure was between 180 and 295 SED (5 to 9 SED/day). Measurements of ambient UVR were not available. In addition to PE, melanin at the cheek was measured before and after the expedition. The increase in melanin of the expeditioners was a 3-4 times higher than those of the Sherpas.

In 2013, Sandberg et al. [158] presented results from a study, which had two novelties: urinary levels of thymine dimmer (DNA-Damage) were correlated to PE and the size of the exposed area of skin was calculated. Participants (lifeguards and agricultural workers in Sweden) wore two PSF badges (both mounted on the top of the shoulders) per day in June and July. One recorded radiant exposure over the work shift, the other one was worn over the whole day. The exposed body size was calculated by taking into account weight, height [159] and clothing (from diary records) of participants. With that, erythemal effective radiant energy (erythemal effective radiant exposure multiplied by exposed area) could be calculated. Radiant energy is important for effects that depend on the size of the exposed skin area and on radiant exposure like Vitamin D photosynthesis or DNA damage. Mean exposure of participants differed by a factor of 5. Daily radiant exposure covered an extreme large range from 0.1 to 32 SED and an even larger did erythemal effective radiant energy ( 1 Jery to 3679 Jery). With that, it is obvious that clothing of people may have an extreme influence on the radiant energy received by the skin. Ambient UVR was calculated using the STRÅNG model [160] and with that mean ERTA was around 20\%.

In 2013, the results from measurements of 122 workers in 10 different outdoor professions were only provided in SED [161]. PE was gained by electronic irradiance meters (X2000-10) on the shoulder in spring and summer in three different years somewhere in Poland (locations and number of days not given). It was found that in $65 \%$ of workers, exposure during work shift exceeds 10 SED (equivalent to 1 MED for sun adapted skin type III).

Once again, PE of schoolteachers in Australia was investigated [162]. The novelties of this pilot study were the usage of badges made from PPO for PE (and ambient) and the calibration in respect to the ICNIRP action spectrum [88] (see Figure 3). The PPO was presented some years before [163] as an alternative to PSF, because it has a larger dynamic range than PSF, allowing PE measurements over up to 4 days at subtropical latitude. However, this was its only application to gain occupational PE. Measurements were taken at the shirt collar of two teachers and took place during November at two high schools in Australia (Toowoomba $\left(27^{\circ} \mathrm{S}\right.$ ) and Emerald $\left(23.5^{\circ} \mathrm{S}\right)$ ). Not surprisingly, it was found that duration of outdoor work is linearly related to PE. Further studies were conducted on Australian teaching staff (classroom teacher, physical education teacher, teacher side and a principal) equipped with PSF badges over 10 working days in November (summer) at Townsville $\left(19^{\circ} \mathrm{S}\right)$ and at Toowoomba $\left(27^{\circ} \mathrm{S}\right)$. Measurements were weighted by the action spectrum of erythema and by that of ACGIH/ICNIRP. As above, teachers who spent more time outdoors (physical education teacher), received higher PE. Median of physical education teachers was below 2 SED but PE of most exceeded the TLV. In the following August (winter), measurements were made again for 5 days. Mean daily PE was higher in winter than in summer, not due to the season but due to differences in timing of outdoor behavior [164,165].

Another mixed-outdoor-indoor occupation was studied by Serrano et al. [166] in two provinces around Valencia $\left(39^{\circ} \mathrm{N}\right.$, Spain). Environmental agents, who could have both outdoor and indoor working activities and were travelling by car, were involved. Eleven of them wore VioSpor badges on wrist and head or wrist and shoulder. Their PE was measured in June, August and September. ERTAs were 7.5\% (0.3-25\%) at the wrist and 9\% at the shoulder (1.7-29\%). 
Three studies on PE of farm and strawberry production workers were published in 2014. However, the published values of PE and the ERTAs did not make sense and did not allow any meaningful conclusions.

Within a European project, Bodeker et al. [167] investigated the PE of farmers, their spouses and their children in four different countries over the main vegetation period (April to October). The participants filled in diaries on an hourly base. Skin colour was measured periodically and vitamin D status was determined in winter and in summer [168]. It was shown that PE does not correlate very well with latitude. The Spanish farmers had the highest exposure, the Austrians the lowest. PE of farmers from Poland and Denmark was in between. Compared to their spouses, the PE of the Spanish farmers (305 SED) was double (135 SED). In Denmark, the ratio was 190 SED to 130 SED. In Poland and Austria, it was vice versa. The spouses had higher total PE than the farmers (Austria: 152:160, Poland: 190:208). The PE of the children is noteworthy: Poland 180 SED (higher than that of Austrian farmers), Denmark 144 SED, Spain 129 SED and Austria 72 SED.

The first attempt to estimate PE of outdoor workers in Africa (Pretoria, $25^{\circ} \mathrm{S}, \mathrm{RSA}$ ) was undertaken by Makgabutlane and Wright [169]. The authors followed an outdoor worker of skin type VI over two days with a handheld irradiance meter and recorded measured UV Index and location with a resolution of 30 min during the work shifts. Later on, Nkogatse et al. [170] performed a study on the PE of female and male car guards in RSA (Potchefstroom, $26^{\circ} \mathrm{S}$ ). Eight volunteers were equipped with proper calibrated electronic meters on the outer side of the left upper arm. ERTA over the works shifts were in the range of $20 \%$ to $40 \%$.

Fortunately, production of renewable energy is on the rise. Among these technologies are solar power plants. As with any plants, these need continuous care. The staff is at essential risk, because solar systems are built in sunny place and free of shade. Rascon et al. [171] have made first estimates of PE to develop sun protection guidelines for plant staff. The estimation based on a maximum UV Index of 12 (Hermosillo Sonora, Mexico $\left(29^{\circ} \mathrm{N}\right)$ ) and the formula for the skin exposure factor according ICNIRP [172]. For the chosen location in Mexico, skin types I-IV are on extreme risk, but also sun adopted V and VI would need care.

A campaign on occupational UV exposure of 15 different professions, divided into mainly outdoor, mixed-indoor-outdoor and indoor workers, was carried out by using electronic PE irradiance meter (possessing an AIGaN photodiode detector) type "Scienterra" (Scienterra Limited, NZ) by Grandahl et al. [173]. The device was worn on the wrist or dorsal forearm. Prior to that, a study was undertaken to examine the properties of the Scienterra and its feasibility for outdoor workers [174]. Final measurements were collected from April to September from more than 400 workers at 50 different sites in Denmark. PE was reported in SED, which allowed at least a kind of ranking, whereas most exposed are roofers (362 SED) followed by concrete workers (280 SED) and road workers (275 SED).

The mainland of Canada covers a wide range of latitudes, reaching southwards as far as Barcelona or Rome in Europe. Therefore, in the south of the country the UV Index may exceed a value of 8. In a first study, Peters et al. [175] investigated the levels of occupational PE (marine construction, land-based construction, horticulture) in Vancouver, Canada, over 40 days using electronic devices (type Scienterra); most clipped on the lapel site, and a few on the wrist and on the hard hat. Meteorological conditions were recorded as well as the UV Index and a simple model was derived to describe PE. Later on, Peters et al. [176] examined the PE of outdoor workers (workers from power utilities and municipalities) in three provinces of Canada (Ontario, British Columbia and Nova Scotia) using PSF mounted mostly on the wrist, and some on the shoulder and hardhat brim from mid July to mid September. They derived ERTAs for several job tasks (e.g., utility line work, supervision tasks etc.) which lay within $15 \%$ and $43 \%$, whereas the municipal workers had half of the PE of the power utilities worker. The PE of a large part exceeded the ICNIRP TLV. Only 14\% of the workers experienced 'acceptable' levels of solar radiation. The model from the first study was used to examine determinants of PE (for both UV radiant exposure and ERTA). 
The model considered badge placement, date, location, industry, main job task, and the hours spent outdoors. In the following, Rydz et al. [177] presented the PE measurements of different outdoor professions in the province of Alberta with respect to TLV.

In 2019, a paper was published that discussed the PE of 7 fishermen, who had been equipped with 9 electronic UVR meters with different spectral responses. The results of this study could not be used due to several ambiguities (e.g., calibration).

Every researcher who has compared PE measurements (especially from electronic devices) and corresponding diaries has noted that both do not match perfectly. While for most participants, differences are quite small and random, some participants tend to overestimate or underestimate their UV exposure permanently. Alshurafa et al. [178] assessed the recall in sun exposure at the end of the day by comparisons against measurements of wristwatchlike electronic personal irradiance meter (type "Shade" YouV Labs Inc., New York, NY, USA) and recognized clearly that participating melanoma survivors underestimate their PE when recalling the day.

Preliminary results of PE for different occupations (taxi driver, street vendor, guards etc.) in Kenya were published in 2019 [179]. Results indicate that PE in respect to the skin type is lower than for Caucasians in Europe.

In 2020, a couple of articles appeared as an outcome of a larger project [180]. Within this project, the PE of outdoor workers from several European countries was collected. For that, a two-channel (UV-A, UV-B/C) electronic irradiance meter (X2012-10, GigahertzOptik, Türkheim, Germany) was worn on the upper arm, which contained also a 3-axis electronic compass and a 3-axis accelerometer. Unfortunately, no information about the calibration is given. The GENESIS-UV measurement system collects only PE without any ambient information. PE measurements from 10 construction workers (of unspecified profession) at two locations in Romania were published in 2020 [181]. The two groups showed different exposure patterns: For one group the measured PE decreased from April to October. For the second group, PE increased from April to July and decreased to October. No information on the workflow or work tasks of both groups was available. From Croatia, the PE of four construction workers was reported [182] and a summary reported PE from outdoor workers in Romania, Croatia, Germany, Denmark and Italy [183].

In 2020, Baczynska et al. $[184,185]$ published the analysis of measurements of pilots equipped with the two-channel meter X2012-10 at the lower chest. From summer 2016 to summer 2017, 18 pilots on around 300 flights, departing from different airports in the UK (Airbus manufactured after 1998), were monitored. Erythema effective UVR could not be detected, but an excess of the ICNIRP threshold for UV-A radiation in 27 flights was found. Even though some of the measured UV-A radiation exposures exceeded the ICNIRP TLV, the monthly averages were lower than the average UV-A exposures of a sample of UK office workers over a similar period.

A similar topic (exposure through glass) is the UV exposure of workers in greenhouses. Transparent glass absorbs UV-B radiation to a wide extends and partly absorbs UV-A radiation (e.g., [186]). For this reason, the erythemally effective irradiance within a glass greenhouse is only $1 \%$ of that outdoors [187]. Nowadays, industrial fruit-growing rarely involves using glass greenhouses, but greenhouses covered by plastics. Transparent or opaque plastic does not absorb UVR in the same manner as glass. Therefore, in 2020 Garcia-Ruiz et al. [188] cared about the risk of greenhouse workers. They examined the erythemally effective UVR inside the most common type of greenhouse in the region of Almera ( $37^{\circ} \mathrm{N}$, Spain). The cover of the greenhouse consisted of 3 layers of polyethylene (each $200 \mu \mathrm{m}$ ). Measurements showed that these layers absorbed only $50 \%$ of the erythemally effective radiation. With that, erythemally effective irradiance inside was up to 5 UV Index (outside: 10 UV Index). A few times during the year, the plastic cover is whitewashed (to avoid stress by high radiation or by heat in the initial stage of the crops). This colouring reduces erythemally UV transmission to $20 \%$, but colour vanishes after a few weeks. With that, one can regard the PE of greenhouse workers as high. 
Within a project that aimed to reduce the PE of British outdoor workers, Cherrie et al. [189] measured the PE (type "Scienterra", back of the hard hat) of a control group and a group that obtained information on UV irradiance via smartphone. Data were collected from 41 workers (758 working days in total) at 9 worksites in Scotland and the Southeast of England between April and July. Daily PE ranged from almost 0 to 13.5 SED, whereas the mean PE was 2 SED. Interestingly, the group using the smartphone information had higher PE than the control group.

Milestones:

- PE and ERTA for a certain occupation can differ more strongly between countries than by latitude [167].

- $\quad$ PE and ERTA for a certain occupation may differ noticeable by gender [27].

- $\quad$ PE in conjunction to urinary levels of thymine dimer (DNA-damage) as biomarker [158].

- $\quad$ PE in conjunction with vitamin D as a biomarker [168].

- Use of poly-dimethyl phenylene oxide film (PPO) badges to measure long term PE [162].

- Calibration in respect to the action spectrum according ICNIRP/ACGIH [162].

- Necessity of proper calibration procedure for electronic PE meter [27].

- $\quad$ Risk days (>10 SED (>4 MED for skin type II)) contribute significantly to total PE [27].

- Occupational PE (e.g., for famers) can be lower than for spouses not working outdoors [167].

- $\quad$ Calculation of exposed skin area due to clothing [158].

- $\quad$ Estimation of received radiant energy [158].

\section{Summary}

Since the 1970s, noticeable progress has been made in measuring techniques and knowledge of PE of outdoor workers (see lists of milestones). PE of a variety of professions and sub-professions was assessed and a clear outcome is that PE of most outdoor workers exceeds the threshold limit value (TLV) issued by ICNIRP/ACGIH [82]. This TLV is equivalent to approximately 1.0 to $1.3 \mathrm{SED}$ (respectively corresponding to 1.1 and $1.5 \mathrm{UV}$ Index hours) and is below the threshold value for erythema even in the most sensitive skin type (2 SED). Staying below that should ensure almost non-hazardous UVR load from occupation.

General risk factors were identified as working in a high UVR environment and/or a monotonic workflow (less movement, nearly static posture). PE of 10 SED and higher has been found as well as PE that exceeds ambient UVR (ERTA $>100 \%$ ) for a few hours or shorter. From this, one can conclude that sun protection tools are necessary which possess a sun protection factor (SPF) higher than 10 to meet the TLV (especially for non-sun-adopted skin). This level of skin protection cannot be provided by simple shadow structures or by wearing a hat, even if both have the ability to halve the PE of outdoor workers. Possible sun protection tools must be protective over the whole UV-wavelength range and may not be effective in a certain range only (e.g., UVB-protection against erythema).

Apart from great progress, there are some matters of concern, which should be mentioned here, to avoid problems in the future:

Reported PE data from the literature are quite heterogeneous. One reason for this is that different measuring positions have been used. It is not possible to generalize from the $\mathrm{PE}$ of a certain body site to the PE of another site. Another reason is that often only radiant exposure values are reported, but no descriptors (e.g., resolved ERTAs) which enable the application of the results to similar cohorts at other locations or dates. Such publications represent, rather, project summaries, but do not improve (useful) knowledge and one could question their scientific validity.

Especially in the past decade, more than half of the studies were not designed or performed in accordance with the available knowledge:

- The measuring position is inadequate: it should be representative for the body part(s), which is (are) most exposed to the sun or/and be selected to allow comparisons. 
- Measurements of ambient UVR are missing or not described: With that, it is impossible to estimate the relative PE (Low, due to cloudiness? High, due to clear sky? etc.) and, therefore, the representativeness of the studies is questionable.

- Lack of a description of calibration or lack of a proper calibration of the PE meters: with that, an uncertainty in measured PE of $\pm 50 \%$ has to be considered. With that, the estimated risk for non-melanoma skin cancer may vary by a factor of 9 .

- Inappropriate statistical descriptors of PE values: solely from the mean value together with standard deviation (which implies a normal distribution), no further conclusions can be drawn (e.g., risk).

- Outdoor work description: without a work-task description of participants or a welldefined sub-profession division, the analysis of PE is jeopardized with respect to risk situations/tasks (very general nomenclatures like construction workers are not helpful).

Beside all these, the use of terms, symbols and units is often inadequate even though an international system exists. This is also published as a glossary, specifically conditioned for the photo-sciences [190]. For proper terms, symbols and units we want also to refer to a specific European standard for measurements and assessment of personal UV exposure $[191,192]$ as well as to some practical advisory articles which are also responsive to this $[84,193,194]$.

At the current stage, meaningful UV exposure data are scarce and it is not yet possible to provide information on a population's UV exposure over a large scale and predict UV exposure over longer exposure periods. However, those studies which are of high quality (around a quarter), coupled with epidemiological data on UVR-induced pathology, may be used in risk assessment and prevention policy (e.g., [195,196]) for a wide variety of environmental and personal conditions. Any improvement of the current state of knowledge on this issue is expected to have great significance for public health.

From all these shortcomings, we suggest that, specific guidelines and a standard protocol should be defined in order to gain objective measures of solar UV exposure of outdoor workers.

Funding: This research received no external funding.

Institutional Review Board Statement: Not applicable.

Informed Consent Statement: Not applicable.

Conflicts of Interest: The authors declare no conflict of interest.

\section{References}

1. Fountoulakis, I.; Diémoz, H.; Siani, A.-M.; Laschewski, G.; Filippa, G.; Arola, A.; Bais, A.F.; De Backer, H.; Lakkala, K.; Webb, A.R.; et al. Solar UV Irradiance in a Changing Climate: Trends in Europe and the Significance of Spectral Monitoring in Italy. Environments 2020, 7, 1. [CrossRef]

2. Webb, A.R.; Kift, R.; Durkin, M.T.; O’Brien, S.J.; Vail, A.; Berry, J.L.; Rhodes, L.E. The role of sunlight exposure in determining the vitamin D status of the U.K. white adult population. Br. J. Dermatol. 2010, 163, 1050-1055. [CrossRef]

3. Unna, P. Ueber das Pigment der menschlichen Haut. Monatsschr. Prakt. Dermatol. 1885, 4, 277-294.

4. Lavker, R.M.; Geberick, G.F.; Veres, D.; Irwin, C.J.; Kaidbey, K.H. Cumulative effects from repeated exposures to suberythemal doses of UVB and UVA in human skin. J. Am. Acad. Dermatol. 1995, 32, 53-62. [CrossRef]

5. Young, A.R.; Orchard, G.E.; Harrison, G.I.; Klock, J.L. The detrimental effects of daily sub-erythemal exposure on human skin in vivo can be prevented by a daily-care broad-spectrum sunscreen. J. Investig. Dermatol. 2007, 127, 975-978. [CrossRef] [PubMed]

6. Bech-Thomsen, N.; Wulf, H.C. Photoprotection due to pigmentation and epidermal thickness after repeated exposure to ultraviolet light and psoralen plus ultraviolet A therapy. Photodermatol. Photoimmunol. Photomed. 1995, 11, 213-218. [CrossRef] [PubMed]

7. Meinhardt, M.; Krebs, R.; Anders, A.; Heinrich, U.; Tronnier, H. Effect of ultraviolet adaption on the ultraviolet absorption spectra oh human skin in vivo. Photodermatol. Photoimmunol. Photomed. 2008, 24, 76-82. [CrossRef]

8. Brenner, M.; Hearing, V.J. The Protective Role of Melanin Against UV Damage in Human Skin. Photochem. Photobiol. 2008, 84, 539-549. [CrossRef]

9. Urbach, F.; Epstein, J.H.; Forbes, P.D. UV carcinogenesis. In Sunlight and Man; Fitzpatrick, T.B., Pathak, M.A., Harber, L.C., Seiji, M., Kutika, A., Eds.; University of Tokyo Press: Tokyo, Japan, 1974; pp. 259-283.

10. Schmalwieser, A.W.; Siani, A.M. Review on Nonoccupational Personal Solar UV Exposure Measurements. Photochem. Photobiol. 2018, 94, 900-915. [CrossRef] 
11. Apalla, Z.; Lallas, A.; Sotiriou, E.; Lazaridou, E.; Ioannides, D. Epidemiological trends in skin cancer. Dermatol. Pract. Concept. 2017, 7, 1-6. [CrossRef]

12. Arnold, M.; de Vries, E.; Whiteman, D.C.; Jemal, A.; Bray, F.; Parkin, D.M.; Soerjomataram, I. Global Burden of cutaneous melanoma attributable to ultraviolet radiation in 2012. Int. J. Cancer 2018, 143, 1305-1314.

13. International Agency for Research on Cancer. Radiation, Volume 100D. A Review of Human Carcinogens. In IARC Monographs on the Evaluation of Carcinogenic Risks to Humans; International Agency for Research on Cancer: Lyon, France, 2012.

14. Fears, T.R.; Scotto, J.; Schneiderman, M.A. Mathematical models of age and ultraviolet effects on the incidence of skin cancer among whites in the United States. Am. J. Epidemiol. 1977, 105, 420-427. [CrossRef] [PubMed]

15. NOHSC. Guidance Note for the Protection of Workers from the Ultraviolet Radiation in Sunlight; NOHSC: 3012; Australian Government Publishing Service: Canberra, Australia, 1991.

16. Diffey, B. The Early Days of Personal Solar Ultraviolet Dosimetry. Atmosphere 2020, 11, 125. [CrossRef]

17. Urbach, F. Geographic pathology of skin cancer. In The Biologic Effects of Ultraviolet Radiation with Emphasis on the Skin; Urbach, F., Ed.; Pergamon Press: Oxford, UK, 1969; pp. 635-650.

18. Davis, A.; Deane, G.H.W.; Diffey, B.L. A preliminary study of a dosimeter for ultraviolet radiation. Nature 1976, 261, 169-170. [CrossRef] [PubMed]

19. Challoner, A.V.J.; Corless, D.; Davis, A.; Deane, G.H.W.; Diffey, B.L.; Gupta, S.P.; Magnus, I.A. Personnel monitoring of exposure to ultraviolet radiation. Clin. Exp. Dermatol. 1976, 1, 175-179. [CrossRef]

20. Mackenzie, L.A.; Frain-Bell, W. The construction and development of grating monochromator and its application to the study of the reaction of the skin to light. Br. J. Dermatol. 1973, 89, 251-264. [CrossRef]

21. Roberston, D.F. Long-term field measurements of erythemally effective natural ultraviolet radiation. In The Biologic Effects of Ultraviolet Radiation with Emphasis on the Skin; Urbach, F., Ed.; Pergamon Press: Oxford, UK, 1969; pp. $433-436$.

22. Berger, D. The sunburning ultraviolet meter: Design and performance. Photochem. Photobiol. 1976, 24, 587-593. [CrossRef]

23. Diffey, B.L.; Kerwin, M.; Davis, A. The anatomical distribution of sunlight. Br. J. Dermatol. 1977, 97, 407-410. [CrossRef]

24. Leach, J.F.; McLeod, V.E.; Pingstone, A.R.; Davis, A.; Deane, G.H.W. Measurement of the ultraviolet doses received by office workers. Clin. Exp. Dermatol. 1978, 3, 77-79. [CrossRef]

25. Diffey, B.L.; Tate, T.J.; Davis, A. Solar dosimetry of the face: The relationship of natural ultraviolet radiation exposure to basal cell carcinoma localisation. Phys. Med. Biol. 1979, 24, 931-939. [CrossRef]

26. Corbett, M.F.; Davis, A.; Magnus, I.A. Personnel radiation dosimetry in drug photosensitivity: Field study of patients on phenothiazine therapy. Br. J. Dermatol. 1978, 98, 39-46. [CrossRef] [PubMed]

27. Schmalwieser, A.W.; Cabaj, A.; Schauberger, G.; Rohn, H.; Maier, B.; Maier, H. Facial solar UV exposure of Austrian farmers during occupation. Photochem. Photobiol. 2010, 86, 1404-1430. [PubMed]

28. Diffey, B.L.; Larko, O.; Swanbeck, G. UV-B Doses received during different outdoor activities and UV-B treatment of Psoriasis. Br. J. Dermatol. 1982, 106, 33-41. [CrossRef]

29. Larkö, O.; Diffey, B.L. Natural UV-B radiation received by people with outdoor, indoor, and mixed occupations and UV-B treatment of psoriasis. Clin. Exp. Dermatol. 1983, 8, 279-285. [CrossRef] [PubMed]

30. Schothorst, A.A.; Slaper, H.; Schouten, R.; Suurmond, D. UVB doses in maintenance psoriasis phototherapy versus solar UVB exposure. Photodermatology 1985, 2, 213-220.

31. Schothorst, A.; Slaper, H.; Telgt, D.; Alhadi, B.; Suurmond, D. Amounts of ultraviolet b (UVB) received from sunlight or artificial sources by various population groups in The Netherlands. In Human Exposure to Ultraviolet Radiation: Risks and Regulations; Passchier, W.F., Bosnjakovic, B.F., Eds.; Elsevier: Amsterdam, The Netherlands, 1987; pp. 269-273.

32. CIE (Commission Internationale de l'Eclairage). Erythema Reference Action Spectrum and Standard Erythema Dose; CIE S007E-1998; CIE Central Bureau: Vienna, Austria, 1998.

33. Holman, C.D.J.; Gibson, I.M.; Stephenson, M.; Armstrong, B.K. Ultraviolet irradiation of human body sites in relation to occupation and outdoor activity: Field studies using personal UVR dosimeters. Clin. Exp. Dermatol. 1983, 8, 269-277. [CrossRef]

34. Schmalwieser, A.W.; Wallisch, S.; Diffey, B. A library of action spectra for erythema and pigmentation. Photochem. Photobiol. Sci. 2012, 11, 251-268.

35. McKinlay, A.F.; Diffey, B.L. A reference action spectrum for ultra-violet induced erythemal in human skin. In Human Exposure to Ultraviolet Radiation: Risks and Regulations; Passchier, W.F., Bosnjakovic, B.F., Eds.; Elsevier: Amsterdam, The Netherlands, 1987; pp. 83-87.

36. McKinlay, A.F.; Diffey, B.L. A reference action spectrum for ultraviolet induced erythemal in human skin. CIE J. 1987, 6, 17-22.

37. Webb, A.R.; Slaper, H.; Koepke, P.; Schmalwieser, A.W. Know your standard: Clarifying the CIE erythema action spectrum. Photochem. Photobiol. 2011, 87, 483-486. [CrossRef]

38. Rosenthal, F.S.; Phoon, C.; Bakalian, A.E.; Taylor, H.R. The ocular dose of ultraviolet radiation to outdoor workers. Investig. Ophthal. Vis. Sci. 1988, 29, 649-656.

39. Diffey, B.L.; Cheesman, J. Sun protection with hats. Br. J. Dermatol. 1992, 127, 10-12. [CrossRef] [PubMed]

40. UNEP; ICNIRP; WHO. Ultraviolet Radiation, Environmental Health Criteria (EHC) 160; WHO: Geneva, Switzerland, 1994.

41. Krueger, A.; Schoeberl, M.; Newman, P.; Stolarski, R. The 1991 Antarctic ozone hole: TOMS observations. Geophys. Res. Lett. 1992, 19, 1215-1218. [CrossRef] 
42. Stolarski, R.S.; Bloomfield, P.; McPeters, R.D.; Herman, J.R. Total ozone trends deduced from NMBUS 7 TOMS Data. Geophys. Res. Lett. 1991, 18, 1015-1018. [CrossRef]

43. Diffey, B.L.; Roscoe, A.H. Exposure to solar ultraviolet radiation in flight. Aviat. Space Environ. Med. 1990, 61, 1032-1035. [PubMed]

44. Rosenthal, F.S.; West, S.K.; Munoz, B.; Emmett, E.A.; Strickland, P.T.; Taylor, H.R. Ocular and facial skin exposure to ultraviolet radiation in sunlight: A personal exposure model with application to a worker population. Health Phys. 1991, 61, 77-86. [CrossRef]

45. Diffey, B.L. Stratospheric ozone depletion and the risk of non-melanoma skin cancer in a British population. Phys. Med. Biol. 1992, 37, 2267-2279. [CrossRef]

46. Schmalwieser, A.W.; Gröbner, J.; Blumthaler, M.; Klotz, B.; De Backer, H.; Bolsée, D.; Werner, R.; Tomsic, D.; Metelka, L.; Eriksen, P.; et al. UV Index monitoring in Europe. Photochem. Photobiol. Sci. 2017, 16, 1349-1370. [CrossRef]

47. Weatherhead, E. Worldwide monitoring and trend analysis. In Measurements and Trends of Terrestrial UVB Radiation in Europe; Diffey, B.L., Ed.; OEMF: Milano, Italy, 1996; pp. 34-39.

48. Berger, D.S.; Urbach, F.A. A climatology of sunburning ultraviolet radiation. Photochem. Photobiol. 1982, 35, 187-192. [CrossRef]

49. Diffey, B.L. The calculation of the spectral distribution of natural ultraviolet radiation under clear day conditions. Phys. Med. Biol. 1977, 22, 309-316. [CrossRef]

50. Green, A.E.S.; Cross, K.R.; South, L.A. Improved analytical characterization of ultraviolet skylight. Photochem. Photobiol. 1979, 31, 59-65. [CrossRef]

51. Stamnes, K.; Tsay, S.-C.; Wiscombe, W.; Jayaweera, K. Numerically stable algorithm for discrete-ordinate-method radiative transfer in multiple scattering and emitting layered media. Appl. Opt. 1988, 27, 2502-2509. [CrossRef] [PubMed]

52. Kneizys, F.X.; Shettle, E.P.; Abreu, L.W.; Chetwynd, J.H.; Anderson, G.P.; Gallery, W.; Selby, J.E.A.; Clough, S.A. LOWTRAN 7, AFGL-TR-88-0177. Environmental Research Papers No. 1010; Air Force Geophysical Laboratory: Hanscom, MA, USA, 1988.

53. Koepke, P.; Bais, A.; Balis, D.; Buchwitz, M.; De Backer, H.; de Cabo, X.; Eckert, P.; Eriksen, P.; Gillotay, D.; Heikkilä, A.; et al. Comparison of models used for UV index calculations. Photochem. Photobiol. 1998, 67, 657-662. [CrossRef] [PubMed]

54. De Backer, H.; Koepke, P.; Bais, A.; De Cabo, X.; Frei, T.; Gillotay, D.; Haite, C.; Heikkilä, A.; Kazantzidis, A.; Koskela, T.; et al. Comparison of measured and modelled uv indices for the assessment of health risks. Meteorol. Appl. 2001, 8, 267-277. [CrossRef]

55. Schmalwieser, A.W.; Schauberger, G.; Erbertseder, T.; Janouch, M.; Coetzee, G.J.; Weihs, P. Sensitivity of erythemally effective UV irradiance and daily exposure to uncertainties in measured total ozone. Photochem. Photobiol. 2006, 83, 433-443. [CrossRef]

56. Schmalwieser, A.W.; Erbertseder, T.; Schauberger, G.; Weihs, P. Sensitivity of UV erythemally effective irradiance and daily dose to spatial variability in total ozone. Photochem. Photobiol. 2008, 84, 1149-1163. [CrossRef]

57. Schmalwieser, A.W.; Erbertseder, T.; Schauberger, G.; Weihs, P. Sensitivity of erythemally effective UV irradiance and daily exposure to temporal variability in total ozone. Photochem. Photobiol. 2008, 85, 261-271. [CrossRef]

58. Diffey, B. Personal ultraviolet radiation dosimetry with polysulphone film badges. Photodermatology 1984, 1, 151-157.

59. Diffey, B.L. A Comparison of dosimeters used for solar ultraviolet radiometry. Photochem. Photobiol. 1987, 46, 55-60. [CrossRef]

60. CIE (Commission Internationale d'Eclairage). Personal Dosimetry of UV Radiation; Technical Report CIE 98-1992; CIE Central Bureau: Vienna, Austria, 1992.

61. Wong, C.F.; Fleming, R.; Carter, S.A. A new dosimeter for ultraviolet-B radiation. Photochem. Photobiol. 1989, 50, 611-615. [CrossRef]

62. Wong, C.F.; Fleming, R.A.; Carter, S.J.; Ring, I.T.; Vishvakarman, D. Measurement of human exposure to ultraviolet-B solar radiation using a CR- 39 dosimeter. Health Phys. 1992, 63, 457-461. [CrossRef]

63. Berces, A.; Fekete, A.; Gaspar, S.; Grof, P.; Rettberg, P.; Horneck, G.; Ronto, G. Biological UV dosimeters in the assessment of the biological hazard from environmental radiation. J. Photochem. Photobiol. B 1999, 53, 36-43. [CrossRef]

64. Rettberg, P.; Horneck, G.; Baumstark-Khan, C.; Amanatidis, G.T. (Eds.) Biological UV Dosimetry, a Tool for Assessing the Impact of UV Radiation on Health and Ecosystems; Air Pollution Research Report 7; Office for Official Publications of the European Communities: Luxembourg, 2000.

65. BWDSUVR (Biologically Weighted Dosimetry of Solar UV Radiation), FP3-ENV 1C, EV5V0342, European Communities, 1994-1995. Available online: https:/ / cordis.europa.eu/project/id/EV5V0342 (accessed on 22 January 2021).

66. BIODOS (Development of Biological Dosimetry Systems for Monitoring the Impact of Solar UVB Radiation on the Biosphere and Human Health), FP4-ENV 2C, ENV4950044, European Communities, 1996-1998. Available online: https: / / cordis.europa.eu/ project/id/ENV4950044/de (accessed on 22 January 2021).

67. Quintern, L.E.; Horneck, G.; Eschweiler, U.; Buecker, H. A biofilm used as ultraviolet-dosimeter. Photochem. Photobiol. 1992, 55, 389-395. [CrossRef]

68. Munakata, N. Killing and mutagenic action of sunlight upon Bacillus subtilis spores: A dosimetric system. Mutat. Res. 1981, 82, 263-268. [CrossRef]

69. Munakata, N.; Kazadzis, S.; Bais, A.F.; Hieda, K.; Rontó, G.; Rettberg, P.; Horneck, G. Comparisons of spore dosimetry and spectral photometry of solar-UV radiation at four sites in Japan and Europe. Photochem. Photobiol. 2000, 72, 739-745. [CrossRef]

70. Munakata, N.; Cornain, S.; Kanoko, M.; Mulyadi, K.; Lestari, S.; Wirohadidjojo, W.; Bolseé, D.; Kazadzis, S.; Meyer-Rochow, V.; Schuch, N.; et al. Biological Monitoring of Solar-UV Radiation at 17 Sites in Asia, Europe and South America from 1999 to 2004. Photochem. Photobiol. 2006, 82, 689-695. [PubMed]

71. Munakata, N.; Kazadzis, S.; Bolseé, D.; Schuch, N.; Koskela, T.; Karpetchko, A.; Meleti, C.; Casiccia, C.; Barcellos da Rosa, M.; Saida, T.; et al. Variations and trends of biologically effective doses of solar ultraviolet radiation in Asia, Europe and South America from 1999 to 2007. Photochem. Photobiol. Sci. 2009, 8, 1117-1124. [CrossRef] 
72. Munakata, N. Blologlcally-effective dose of solar ultraviolet radiation estimated by spore dosimetry in Tokyo since 1980. Photochem. Photobiol. 1993, 58, 386-392. [CrossRef]

73. Quintern, L.E.; Puskeppeleit, M.; Rainer, P.; Weber, S.; el Naggar, S.; Eschweiler, U.; Horneck, G. Continuous dosimetry of the biologically harmful UV-radiation in Antarctica with the biofilm technique. J. Photochem. Photobiol. B 1994, 22, 59-66. [CrossRef]

74. Horneck, G. Quantification of the biological effectiveness of environmental UV radiation. J. Photochem. Photobiol. B 1995 31, 43-49. [CrossRef]

75. Quintern, L.E.; Furusawa, K.; Fukutsu, K.; Holtschmidt, H. Characterization and application of UV detector spore films: The sensitivity curve of a new detector system provides good similarity to the action spectrum for UV-induced erythema in human skin. J. Photochem. Photobiol. B 1997, 37, 158-166. [CrossRef]

76. Galkin, O.N.; Terenetskaya, I.P. Vitamin D' biodosimeter: Basic characteristics and potential applications. J. Photochem. Photobiol. B 1999, 53, 12-19. [CrossRef]

77. Knapp, R.G.; Miller, M.C. Clinical Epidemiology and Biostatistics; Williams and Wilkins: Baltimore, MD, USA, 1992.

78. Herlihy, E.; Gies, H.P.; Roy, C.R.; Jones, M. Personal dosimetry of solar UVR for different outdoor activities. Photochem. Photobiol. 1994, 60, 288-294. [CrossRef] [PubMed]

79. ICNIRP (International Commission on Non-Ionizing Radiation Protection). Global Solar UV-Index-WHO/WMO/ICNIRP Recommendation; ICNIRP publication No.1/95; ICNIRP: Oberschleissheim, Germany, 1995.

80. CIE (Commission Internationale d'Eclairage). Erythema Reference Action Spectrum and Standard Erythema Dose; ISO/CIE 17166:2019(E); CIE Central Bureau: Vienna, Austria, 2019.

81. Wester, U. Analytic expressions to represent the hazard ultra-violet action spectrum of ICNIRP and ACGIH. Radiat. Protect. Dosim. 2000, 91, 231-232. [CrossRef]

82. ICNIRP (International Commission on Non-Ionizing Radiation Protection). Guidelines on limits of exposure to ultraviolet radiation of wavelengths between $180 \mathrm{~nm}$ ad $400 \mathrm{~nm}$ (incoherent optical radiation). Health Phys. 2004, 87, 171-186. [CrossRef] [PubMed]

83. Vanicek, K.; Frei, T.; Litynska, Z.; Schmalwieser, A. UV Index for the Public; COST-713; European Communities: Brussels, Belgium, 2000.

84. WHO (World Health Organization). Global Solar UV Index: A Practical User Guide; WHO: Geneva, Switzerland, 2002.

85. Saxebøl, G. UVIh-A proposal for a practical unit for biological effective dose for ultraviolet radiation exposure. Radiat. Prot. Dosim. 2000, 88, 261-264. [CrossRef]

86. Schmalwieser, A.W. Possibilities to estimate the personal UV radiation exposure from ambient UV radiation measurements. Photochem. Photobiol. Sci. 2020, 19, 1249-1261. [CrossRef] [PubMed]

87. ACGIH (American Conference of Governmental Industrial Hygienists). Threshold Limit Values of Physical Agents Adopted by ACGIH for 1971; ACGIH: Cincinnati, OH, USA, 1971.

88. Sliney, D.H. The merits of an envelope action spectrum for ultraviolet radiation exposure criteria. Am. Ind. Hyg. Assoc. J. 1972, 33, 644-653. [CrossRef]

89. IRPA. Guidelines on limits of exposure to ultraviolet radiation of wavelengths between $180 \mathrm{~nm}$ and $400 \mathrm{~nm}$ (incoherent optical radiation). Health Phys. 1985, 49, 331-340.

90. IRPA/INIRC. Proposed change to the IRPA 1985 guidelines on limits of exposure to ultraviolet radiation. Health Phys. 1989, $56,971-972$.

91. National Health and Medical Research Council. Occupational Standard for Exposure to Ultraviolet Radiation; Radiation Health Series No.29; NHMRC: Canberra, Australia, 1989.

92. Gies, H.P.; Roy, C.R.; Toomey, S.; MacLennan, R.; Watson, M. Solar UVR exposures of three groups of outdoor workers on the Sunshine Coast, Queensland. Photochem. Photobiol. 1995, 62, 1015-1021. [CrossRef]

93. Diffey, B.L.; Saunders, P.J. Behavior outdoors and its effects on personal ultraviolet exposure rate measured using an ambulatory datalogging dosimeter. Photochem. Photobiol. 1995, 61, 615-618. [CrossRef] [PubMed]

94. Wulf, H.C.; Gniadecka, M. CaF2: Dy and CaF2 crystal-based UV dosimeters. Skin Res. Technol. 1996, 2, 108-113. [CrossRef] [PubMed]

95. Wulf, H.C.; Gniadecka, M. Electronic UV dosimeters. Skin Res. Technol. 1996, 2, 103-107. [CrossRef] [PubMed]

96. Naggar, S.E.; Gustat, H.; Magister, H.; Rochlitzer, R. An electronic personal UV-B-dosimeter. J. Photochem. Photobiol. B 1995, 31, 83-86. [CrossRef]

97. Knuschke, P.; Barth, J. Biologically weighted personal UV dosimetry. J. Photochem. Photobiol. B 1996, 36, 77-83. [CrossRef]

98. Kimlin, M.G.; Wong, J.C.F.; Parisi, A.V. A simultaneous comparison of the personal UV exposure of two human groups at different altitudes. Health Physics 1998, 74, 429-434. [CrossRef]

99. Blumthaler, M.; Ambach, W.; Rehwald, W. Solar UV-A and UV-B radiation fluxes at two Alpine stations at different altitudes. Theor. Appl. Climatol. 1992, 46, 39-44. [CrossRef]

100. Schmalwieser, A.W.; Klotz, B.; Schwarzmann, M.; Baumgartner, D.J.; Schreder, J.; Schauberger, G.; Blumthaler, M. The Austrian UVA-Network. Photochem. Photobiol. 2019, 95, 1258-1266. [CrossRef]

101. Kimlin, M.G.; Parisi, A.V.; Wong, J.C.F. Quantification of personal solar UV exposure of outdoor workers, indoor workers and adolescents at two locations in Southeast Queensland. Photodermatol. Photoimmunol. Photomed. 1998, 14, 7-11. [CrossRef]

102. Parisi, A.V.; Meldrum, L.R.; Kimlin, M.G.; Wong, J.C.F.; Aitken, J.; Mainstone, J.S. Evaluation of differences in ultraviolet exposure during weekend and weekday activities. Phys. Med. Biol. 2000, 45, 2253-2262. [CrossRef]

103. Diffey, B.L.; Gibson, C.J.; Haylock, R.; McKinlay, A.F. Outdoor ultraviolet exposure of children and adolescents. Br. J. Dermatol. 1996, 134, 1030-1034. [CrossRef] [PubMed] 
104. Parisi, A.; Kimlin, M.G.; Mainstone, J.S. Variations in solar erythemal ultraviolet occupational exposure due to daylight saving time in Australia. Radiat. Prot. Australas. 1999, 16, 13-20.

105. Krins, A.; Bolsee, D.; Doerschel, B.; Gillotay, D.; Knuschke, P. Angular dependence of the efficiency of the UV sensor polysulphone film. Radiat. Protect. Dosim. 2000, 87, 261-266. [CrossRef]

106. Krins, A.; Dorschel, B.; Knuschke, P.; Seidlitz, H.K.; Thiel, S. Determination of the calibration factor of polysulfone film UV dosimeters for terrestrial solar-radiation. Radiat. Protect. Dosim. 2001, 95, 345-352. [CrossRef]

107. Casale, G.R.; Borra, M.; Colosimo, A.; Colucci, M.; Militello, A.; Siani, A.M.; Sisto, R. Variability among polysulphone calibration curves. Phys. Med. Biol. 2006, 51, 4413-4427. [CrossRef]

108. Siani, A.M.; Casale, G.R.; Modesti, S.; Parisi, A.V.; Colosimo, A. Investigation on the capability of polysulphone for measuring biologically effective solar UV exposures. Photochem. Photobiol. Sci. 2014, 13, 521-530. [CrossRef]

109. CIE (Commission Internationale de l'Eclairage). Action Spectrum for the Production of Previtamin D3 in Human Skin; CIE 174:2006; CIE Central Bureau: Vienna, Austria, 2006.

110. Moehrle, M.; Korn, M.; Garbe, C. Bacillus subtilis spore film dosimeters in personal dosimetry for occupational solar ultraviolet exposure. Int. Arch. Occup. Environ. Health 2000, 73, 575-580. [CrossRef]

111. Moehrle, M.; Garbe, C. Personal UV dosimetry by Bacillus subtilis spore films. Dermatology 2000, 200, 1-5. [CrossRef]

112. Moehrle, M.; Dennenmoser, B.; Garbe, C. Continous long-term monitoring of UV radiation in professional mountain guides reveals extreme high exposure. Int. J. Cancer 2003, 103, 775-778. [CrossRef]

113. Thieden, E.; Ågren, M.S.; Wulf, H.C. Solar UVR exposures of indoor workers in a Working and a Holiday Period assessed by personal dosimeters and sun exposure diaries. Photodermatol. Photoimmunol. Photomed. 2001, 17, 249-255. [CrossRef]

114. Thieden, E.; Agren, M.S.; Wulf, H.C. The wrist is a reliable body site for personal dosimetry of ultraviolet radiation. Photodermatol. Photoimmunol. Photomed. 2000, 16, 57-61. [CrossRef] [PubMed]

115. Vishvakarman, D.; Wong, J.C.F.; Boreham, B.W. Annual occupational exposure to ultraviolet radiation in central Queensland. Health Phys. 2001, 81, 536-544. [CrossRef] [PubMed]

116. Cockell, C.; Horneck, G.; Rettberg, P.; Arendt, J.; Scherer, K.; Facius, R.; Gugg-Helminger, A. Human exposure to ultraviolet radiation at the, Antipodes-A comparison between an Antarctic $\left(67^{\circ} \mathrm{S}\right)$ and Arctic $\left(75^{\circ} \mathrm{N}\right)$ location. Polar Biol. 2002, 25, 492-499. [CrossRef]

117. Cockell, C.S.; Scherer, K.; Horneck, G.; Rettberg, P.; Facius, R.; Gugg-Helminger, A.; Driscoll, C.; Lee, P. Exposure of Arctic Field Scientists to Ultraviolet Radiation Evaluated Using Personal Dosimeters. Photochem. Photobiol. 2001, 74, 570-578. [CrossRef]

118. Gies, P.; Wright, J. Measured Solar Ultraviolet Radiation Exposures of Outdoor Workers in Queensland in the Building and Construction Industry. Photochem. Photobiol. 2003, 78, 342-348. [CrossRef]

119. Roy, C.R.; Gies, H.P.; Toomey, S. The solar UV radiation environment: Measurement techniques and results. J. Photochem. Photobiol. B 1995, 31, 21-27. [CrossRef]

120. Thieden, E.; Philipsen, P.A.; Heydenreich, J.; Wulf, H.C. UV Radiation Exposure Related to Age, Sex, Occupation, and Sun Behavior Based on Time-Stamped Personal Dosimeter Readings. Arch. Dermatol. 2004, 140, 197-203. [CrossRef]

121. Thieden, E.; Philipsen, P.A.; Wulf, H.C. Compliance and data reliability in sun exposure studies with diaries and personal, electronic UV dosimeters. Photodermatol. Photoimmunol. Photomed. 2006, 22, 93-99. [CrossRef]

122. Thieden, E.; Philipsen, P.A.; Sandby-Møller, J.; Heydenreich, J.; Wulf, H.C. Proportion of Lifetime UV Dose Received by Children, Teenagers and Adults Based on Time-Stamped Personal Dosimetry. J. Investig. Dermatol. 2004, 123, 1147-1150.

123. Thieden, E.; Philipsen, P.A.; Sandby-Møller, J.; Wulf, H.C. Sunburn Related to UV Radiation Exposure, Age, Sex, Occupation, and Sun Bed Use Based on Time-Stamped Personal Dosimetry and Sun Behavior Diaries. Arch. Dermatol. 2005, 141, 482-488. [CrossRef]

124. Thieden, E.; Philipsen, P.A.; Sandby-Møller, J.; Wulf, H.C. Sunscreen Use Related to UV Exposure, Age, Sex, and Occupation Based on Personal Dosimeter Readings and Sun-Exposure Behavior Diaries. Arch. Dermatol. 2005, 141, 967-973. [CrossRef] [PubMed]

125. Heydenreich, J.; Wulf, H.C. Miniature personal electronic UVR dosimeter with erythema response and time-stamped readings in a wristwatch. Photochem. Photobiol. 2005, 81, 1138-1144. [CrossRef] [PubMed]

126. Heydenreich, J.; Wulf, H.C. Personal electronic UVR dosimeter measurements: Specific and general uncertainties. Photochem. Photobiol. Sci. 2019, 18, 1461-1470. [CrossRef] [PubMed]

127. Fitzpatrick, T.B.; Pathak, M.; Parrish, J.A. Protection of human skin against the effects of the sunburn ultraviolet (290-320 nm). In Sunlight and Man: Normal and Abnormal Photobiologic Responses; Pathak, M.A., Harber, L.C., Seiji, M., Kukita, A., Eds.; University of Tokyo Press: Tokyo, Japan, 1974; p. 751.

128. Thieden, E.; Collins, S.M.; Philipsen, P.A.; Murphy, G.M.; Wulf, H.C. Ultraviolet exposure patterns of Irish and Danish gardeners during work and leisure. Br. J. Dermatol. 2005, 153, 795-801. [CrossRef] [PubMed]

129. Thieden, E.; Philipsen, P.A.; Wulf, H.C. Ultraviolet radiation exposure pattern in winter compared with summer based on time-stamped personal dosimeter readings. Br. J. Dermatol. 2006, 154, 133-138. [CrossRef]

130. Weber, M.; Graber, F.; Schulmeister, K.; Brusl, H.; Hann, H.; Kindl, P.; Knuschke, P. Solar UVR exposure of outdoor workers (tinsmiths) in Austria. UV radiation and its effects-An update. J. R. Soc. N. Z. 2006, 68, 99-100.

131. Turner, J.; Parisi, A.V. Ultraviolet Radiation Albedo and Reflectance in Review: The Influence to Ultraviolet Exposure in Occupational Settings. Int. J. Environ. Res. Public Health 2018, 15, 1507. [CrossRef]

132. Schmalwieser, A.W.; Schauberger, G. A monitoring network for erythemally-effective solar ultraviolet radiation in Austria: Determination of the measuring sites and visualisation of the spatial distribution. Theor. Appl. Climatol. 2001, 69, 221-229. [CrossRef]

133. Blumthaler, M.; Klotz, B.; Schwarzmann, M.; Schreder, J. The Austrian UV Monitoring Network. AIP Conf. Proc. 2017, $1810,110001$. 
134. Weber, M.; Uller, A.; Schulmeister, K.; Brusl, H.; Hann, H.; Kindl, P. Outdoor Workers' Acceptance of Personal Protective Measures Against Solar Ultraviolet Radiation. Photochem. Photobiol. 2007, 83, 1471-1480. [CrossRef]

135. Weber, M.; Schulmeister, K.; Brusl, H. Parameters influencing the accuracy and practical applicability of UV indicator cards. Photochem. Photobiol. Sci. 2006, 5, 707-713. [CrossRef] [PubMed]

136. Milon, A.; Sottas, P.-E.; Bulliard, J.-L.; Vernez, D. Effective exposure to solar UV in building workers: Influence of local and individual factors. J. Exp. Sci. Env. Epidem. 2007, 17, 58-68. [CrossRef] [PubMed]

137. Bener, P. Investigation of the Spectral Intensity of Ultraviolet Sky and Sun + Sky Radiation (between 297.5 and $370 \mathrm{~nm}$ ) under Different Conditions of Cloudless Weather at 1590 ma.s.l.; Contract AF61(052)-54, Technical Summary n.1; Physikalisch-Meteorologisches Observatorium Davos: Davos Platz, Switzerland, 1960.

138. Blumthaler, M.; Ambach, W. Human solar ultraviolet radiant exposure in high mountains. Atmos. Environ. 1988, 22, 749-753. [CrossRef]

139. Simic, S.; Fitzka, M.; Schmalwieser, A.; Weihs, P.; Hadzimustafic, J. Factors affecting UV irradiance at selected wavelengths at Hoher Sonnblick. Atmos. Res. 2011, 101, 869-878. [CrossRef]

140. Siani, A.M.; Casale, G.R.; Diémoz, H.; Agnesod, G.; Kimlin, M.G.; Lang, C.A.; Colosimo, A. Personal UV exposure in high albedo alpine sites. Atmos. Chem. Phys. 2008, 8, 3749-3760. [CrossRef]

141. CIE (Commission Internationale d'Eclairage). CIE 1976 Uniform Color Spaces, Colorimetry; CIE Publication: Vienna, Austria, 1976; pp. 29-32.

142. Casale, G.R.; Siani, A.M.; Diémoz, H.; Agnesod, G.; Parisi, A.V.; Colosimo, A. Extreme UV index and solar exposures at plateau rosà (3500 ma.s.1.) in valle d'aosta Region, Italy. Sci. Total Environ. 2015, 512-513, 622-630. [CrossRef]

143. Gies, P.; Glanz, K.; O’Riordan, D.; Elliott, T.; Nehl, E. Measured Occupational Solar UVR Exposures of Lifeguards in Pool Settings. Am. J. Ind. Med. 2009, 52, 645-653. [CrossRef]

144. O'Riordan, D.L.; Glanz, K.; Gies, P.; Elliott, T. A Pilot Study of the Validity of Self-reported Ultraviolet Radiation Exposure and Sun Protection Practices Among Lifeguards, Parents and Children. Photochem. Photobiol. 2008, 84, 774-778. [CrossRef]

145. Serrano, M.A.; Canada, J.; Moreno, J.C. Erythemal Ultraviolet Exposure in Two Groups of Outdoor Workers in Valencia, Spain. Photochem. Photobiol. 2009, 85, 1468-1473. [CrossRef]

146. Gies, P.; Watzl, R.; Javorniczky, J.; Roy, C.; Henderson, S.; Kingston, J.A.M. Measurement of the UVR Exposures of Expeditioners on Antarctic Resupply Voyages. Photochem. Photobiol. 2009, 85, 1485-1490. [CrossRef]

147. Glanz, K.; Gies, P.; O’Riordan, D.L.; Elliott, T.; Nehl, E.; McCarty, F.; Davis, E. Validity of self-reported solar UVR exposure compared with objectively measured UVR exposure. Cancer Epidemiol. Biomark. Prev. 2010, 19, 3005-3012. [CrossRef] [PubMed]

148. Hammond, V.; Reeder, A.I.; Gray, A. Patterns of real-time occupational ultraviolet radiation exposure among a sample of outdoor workers in New Zealand. Public Health 2009, 123, 182-187. [CrossRef] [PubMed]

149. Allen, M.; McKenzie, R. Enhanced UV exposure on a ski-field compared with exposures at sea level. Photochem. Photobiol. Sci. 2005, 4, 429-437. [CrossRef] [PubMed]

150. Allen, M.W.; Swift, N.; Nield, K.M.; Liley, B.; McKenzie, R.L. Use of Electronic UV Dosimeters in Measuring Personal UV Exposures and Public Health Education. Atmosphere 2020, 11, 744.

151. Schmid-Kubista, K.E.; Kellner, L.; Maier, H.; Felke, S.; Wanka, A.; El Modeir, A.; Schmidt, J.B.; Cabaj, A.; Schmalwieser, A.; Rohn, H.; et al. Effect of work-related ultraviolet exposure and ophthalmic changes in Austrian farmers: The SVB-UV study. Ophthalmic Res. 2010, 43, 201-207. [CrossRef]

152. Maier, H.; Schmalwieser, A.W. Sunscreens and occupation: The Austrian experience. Photochem. Photobiol. Sci. 2010, 9, 510-515. [PubMed]

153. Siani, A.M.; Casale, G.R.; Sisto, R.; Colosimo, A.; Lang, C.A.; Kimlin, M.G. Occupational Exposures to Solar Ultraviolet Radiation of Vineyard Workers in Tuscany (Italy). Photochem. Photobiol. 2011, 87, 925-934. [PubMed]

154. Serrano, M.-A.; Cañada, J.; Moreno, J.C. Solar UV exposure in construction workers in Valencia, Spain. J. Expo. Sci. Environ. Epidemiol. 2012, 23, 525-530.

155. Feister, U.; Meyer, G.; Kirst, U. Solar UV radiation exposure of seamen-Measurements, calibration and model calculations of erythemal irradiance along ship routes. AIP Conf. Proc. 2013, 1531, 860-863.

156. Feister, U.; Meyer, G.; Kirst, U. Solar UV exposure of seafarers along subtropical and tropical shipping Routes. Photochem. Photobiol. 2013, 89, 1497-1506.

157. Cheng, I.; Kiss, A.; Lilge, L. An Observational Study of Personal Ultraviolet Dosimetry and Acute Diffuse Reflectance Skin Changes at Extreme Altitude. Wilderness Environ. Med. 2013, 24, 390-396. [CrossRef] [PubMed]

158. Sandberg Liljendahl, T.; Blomqvist, A.; Andersson, E.M.; Barregard, L.; Segerbäck, D. Urinary levels of thymine dimer as a biomarker of exposure to ultraviolet radiation in humans during outdoor activities in the summer. Mutagenesis 2013, 28, 249-256. [CrossRef] [PubMed]

159. Du Bois, D.; Du Bois, E.F. A formula to estimate the approximate surface area if height and weight be known. Arch. Intern. Med. 1916, 17, 863-871. [CrossRef]

160. Landelius, T.; Josefsson, W.; Persson, T. SMHI (STRÅNG): A System for Modelling Solar Radiation Parameters with Mesoscale Spatial Resolution; SMHI Reports, RMK. No. 96; SMHI: Norrkoping, Sweden, 2001.

161. Wolska, A. Occupational exposure to solar ultraviolet radiation of polish outdoor workers: Risk estimation method and criterion. Int. J. Occup. Saf. Ergon. 2013, 19, 107-116. [CrossRef] [PubMed]

162. Downs, N.J.; Parisi, A.V.; Igoe, D. Measurements of occupational ultraviolet exposure and the implications of timetabled yard duty for school teachers in Queensland, Australia: Preliminary results. J. Photochem. Photobiol. B 2014, 31, 84-89. [CrossRef] [PubMed] 
163. Lester, R.A.; Parisi, A.V.; Kimlin, M.G.; Sabburg, J. Optical Properties of poly(2,6-dimethyl-1,4-phenylene Oxide) Film and Its Potential for a Long-Term Solar Ultraviolet Dosimeter. Phys. Med. Biol. 2003, 22, 3685-3698. [CrossRef]

164. Downs, N.J.; Harrison, S.L.; Garzon Chavez, D.R.; Parisi, A.V. Solar ultraviolet and the occupational radiant exposure of Queensland school teachers: A comparative study between teaching classifications and behavior patterns. J. Photochem. Photobiol. B 2016, 158, 105-112. [CrossRef]

165. Downs, N.J.; Igoe, D.P.; Parisi, A.V.; Taylor, O.; Lazzaroni, S.L.; Rawlings, A.; Garzon-Chavez, D.R.; Harrison, S.L. Seasonal Minimum and Maximum Solar Ultraviolet Exposure Measurements of Classroom Teachers Residing in Tropical North Queensland, Australia. Photochem. Photobiol. 2019, 95, 1083-1093. [CrossRef]

166. Serrano, M.-A.; Cañada, J.; Moreno, J.C.; Gurrea, G. Occupational UV exposure of environmental agents in Valencia, Spain. Photochem. Photobiol. 2014, 90, 911-918. [CrossRef]

167. Bodekær, M.; Harrison, G.I.; Philipsen, P.; Petersen, B.; Triguero-Mas, M.; Schmalwieser, A.W.; Rogowski-Tylman, M.; Dadvand, P.; Lesiak, A.; Narbutt, J.; et al. Personal UVR exposure of farming families in four European countries. J. Photochem. Photobiol. $B$ 2015, 153, 267-275. [CrossRef]

168. Bodekær, M.; Petersen, B.; Thieden, E.; Philipsen, P.; Heydenreich, J.; Olsen, P.; Wulf, H.C. UVR exposure and vitamin D in a rural population. A study of outdoor working farmers, their spouses and children. Photochem. Photobiol. Sci. 2014, 13, 1598-1606. [CrossRef] [PubMed]

169. Makgabutlane, M.; Wright, C.Y. Real-time measurements of outdoor worker's exposure to solar ultraviolet radiation in Pretoria, South Africa. South Afr. J. Sci. 2015, 111, 1-7.

170. Nkogatse, M.M.; Ramotsehoa, M.C.; Eloff, F.C.; Wright, C.Y. Solar Ultraviolet Radiation Exposure and Sun Protection Behaviors and Knowledge Among a High-Risk and Overlooked Group of Outdoor Workers in South Africa. Photochem. Photobiol. 2019, 95, 439-445. [CrossRef] [PubMed]

171. Rascon, D.S.; Ferreira, A.D.; da Silva, M.G. Cumulative and momentary skin exposures to solar radiation in central receiver solar systems. Energy 2017, 137, 336-349. [CrossRef]

172. ICNIRP (International Commission on Non-Ionizing Radiation Protection). Protecting Workers from Ultraviolet Radiation; ICNIRP: Oberschleißheim, Germany, 2007.

173. Grandahl, K.; Eriksen, P.; Ibler, K.S.; Bonde, J.P.; Mortensen, O.S. Measurements of Solar Ultraviolet Radiation Exposure at Work and at Leisure in Danish Workers. Photochem. Photobiol. 2018, 94, 807-814. [CrossRef] [PubMed]

174. Grandahl, K.; Mortensen, O.S.; Sherman, D.Z.; Køster, B.; Lund, P.-A.; Ibler, K.S.; Eriksen, P. Solar UV exposure among outdoor workers in Denmark measured with personal UV-B dosimeters: Technical and practical feasibility. BioMed. Eng. OnLine 2017, 16, 119. [CrossRef]

175. Peters, C.E.; Demers, P.A.; Kalia, S.; Nicol, A.-M.; Koehoorn, M.W. Levels of Occupational Exposure to Solar Ultraviolet Radiation in Vancouver, Canada. Occup. Hyg. 2016, 60, 825-835. [CrossRef] [PubMed]

176. Peters, C.E.; Pasko, E.; Strahlendorf, P.; Holness, D.L.; Tenkate, T. Solar Ultraviolet Radiation Exposure Among Outdoor Workers in Three Canadian Provinces. Ann. Work Expo. Health 2019, 63, 679-688. [CrossRef]

177. Rydz, E.; Harper, A.; Leong, B.; Arrandale, V.H.; Kalia, S.; Forsman-Phillips, L.; Holness, D.L.; Tenkate, T.; Peters, C.E. Solar ultraviolet radiation exposure among outdoor workers in Alberta, Canada. Environ. Res. 2020, 189, 109902. [CrossRef]

178. Alshurafa, N.; Jain, J.; Stump, T.K.; Spring, B.; Robinson, J.K. Assessing recall of personal sun exposure by integrating UV dosimeter and selfreported data with a network flow framework. PLoS ONE 2019, 14, e0225371. [CrossRef]

179. Schoder, D.; Heydenreich, J.; Schmalwieser, A.W. First Results From Personal UV Exposure Measurements In Kenya. In Proceedings of the ESP-IUBP World Congress, Barcelona, Spain, 25-30 August 2019; p. 477.

180. Wittlich, M.; Westerhausen, S.; Kleinespel, P.; Rifer, G.; Stöppelmann, W.J. An approximation of occupational lifetime UVR exposure: Algorithm for retrospective assessment and current measurements. Eur. Acad. Dermatol. Venereol. 2016, 30 (Suppl. 3), 27-33. [CrossRef] [PubMed]

181. Moldovan, H.R.; Wittlich, M.; John, S.M.; Brans, R.; Tiplica, G.S.; Salavastru, C.; Toader, S.; Voidazan, S.T.; Duca, R.C.; Fugulyan, E.; et al. Exposure to solar UV radiation in outdoor construction workers using personal dosimetry. Environ. Res. 2020, 181, 108967. [CrossRef] [PubMed]

182. Kovačić, J.; Wittlich, M.; John, S.M.; Macan, J. Personal ultraviolet radiation dosimetry and its relationship with environmental data: A longitudinal pilot study in Croatian construction workers. J. Photochem. Photobiol. B 2020, 207, 111866. [CrossRef] [PubMed]

183. Wittlich, M.; John, S.M.; Tiplica, G.S.; Sălăvăstru, C.M.; Butacu, A.I.; Modenese, A.; Paolucci, V.; D’Hauw, G.; Gobba, F.; Sartorelli, P.; et al. Personal solar ultraviolet radiation dosimetry in an occupational setting across Europe. J. Eur. Acad. Dermatol. Venereol. 2020, 34, 1835-1841. [CrossRef] [PubMed]

184. Baczynska, K.A.; Brown, S.; Chorley, A.C.; Lyachev, A.; Wittlich, M.; Khazova, M. Me asurements of UV—A Exposure of Commercial Pilots Using Genesis-UV Dosimeters. Atmosphere 2020, 11, 475. [CrossRef]

185. Baczynska, K.A.; Brown, S.; Chorley, A.C.; O’Hagan, J.B.; Khazova, M.; Lyachev, A.; Wittlich, M. In-flight UV-A exposure of commercial airline pilots. Aerosp. Med. Hum. Perform. 2020, 91, 1-10. [CrossRef]

186. Parisi, A.V.; Turnbull, D.J.; Kimlin, M.G. Dosimetric and spectroradiometric investigations of glass filtered solar UV. Photochem. Photobiol. 2007, 83, 777-781. [CrossRef]

187. Parisi, A.V.; Wong, J.C. The erythemal ultraviolet exposure for humans in greenhouses. Phys. Med. Biol. 1997, 42, 2331-2339. [CrossRef] 
188. García-Ruiz, R.A.; López-Martínez, J.; Blanco-Claraco, J.L.; Pérez-Alonso, J.; Callejón-Ferre, Á.J. Ultraviolet Index (UVI) inside an Almería-Type Greenhouse (Southeastern Spain). Agronomy 2020, 10, 145. [CrossRef]

189. Cherrie, J.W.; Nioi, A.; Wendelboe-Nelson, C.; Cowan, S.; Cherrie, M.; Rashid, S.; Cowie, H.; Ritchie, P.; Lansdown, T.C. Exposure to Solar UV During Outdoor Construction Work in Britain. Ann. Work Expo. Health 2020, wxaa028. [CrossRef]

190. IUPAC (International Union of Pure and Applied Chemistry). Glossary of Terms Used in Photochemistry 3rd Edition (IUPAC Recommendations 2006). Pure Appl. Chem. 2007, 79, 293-465. [CrossRef]

191. EN 14255-3:2008 Measurement and Assessment of Personal Exposures to Incoherent Optical Radiation-Part 3: UV-Radiation Emitted by the Sun; European Communities: Brussels, Belgium, 2008.

192. EN 14255-4:2006 Measurement and Assessment of Personal Exposures to Incoherent Optical Radiation—Part 4: Terminology and Quantities Used in UV-, Visible and IR-Exposure Measurements; European Communities: Brussels, Belgium, 2008.

193. Knuschke, P. UV Exposure. In Kanerva's Occupational Dermatology; John, S., Johansen, J., Rustemeyer, T., Elsner, P., Maibach, H., Eds.; Springer: Cham, Switzerland, 2018; p. 36.

194. Sliney, D.H. Radiometric Quantities and Units Used in Photobiology and Photochemistry: Recommendations of the Commission Internationale de l'Eclairage (International Commission on Illumination). Photochem. Photobiol. $2007,83,425-432$. [CrossRef] [PubMed]

195. Thomas Tenkate, T.; Adam, B.; Al-Rifai, R.H.; Chou, B.R.; Gobba, F.; Ivanov, I.D.; Leppink, N.; Loney, T.; Pega, F.; Peters, C.E.; et al. WHO/ILO work-related burden of disease and injury: Protocol for systematic reviews of occupational exposure to solar ultraviolet radiation and of the effect of occupational exposure to solar ultraviolet radiation on cataract. Environ. Int. 2019, 125, 542-553. [CrossRef] [PubMed]

196. Silva Paulo, M.; Adam, B.; Akagwu, C.; Akparibo, I.; Al-Rifaia, R.H.; Bazrafshane, S.; Gobbaf, F.; Green, A.C.; Ivanov, I.; Kezic, S.; et al. WHO/ILO work-related burden of disease and injury: Protocol for systematic reviews of occupational exposure to solar ultraviolet radiation and of the effect of occupational exposure to solar ultraviolet radiation on melanoma and non-melanoma skin cancer. Environ. Int. 2019, 126, 804-815. [CrossRef] [PubMed] 